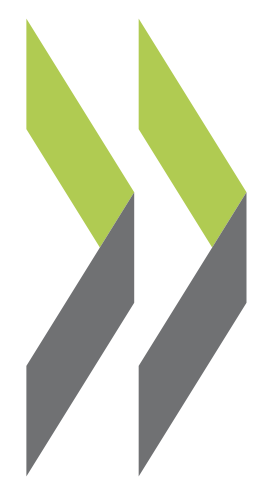

OECD Social, Employment and Migration Working Papers No. 49

\title{
The Labour Market Integration of Immigrants in Australia
}


The Labour Market Integration of Immigrants in Australia

Thomas Liebig 
Organisation de Coopération et de Développement Economiques

Organisation for Economic Co-operation and Development

22-Feb-2007

DIRECTORATE FOR EMPLOYMENT, LABOUR AND SOCIAL AFFAIRS

English - Or. English

EMPLOYMENT, LABOUR AND SOCIAL AFFAIRS COMMITTEE

OECD SOCIAL, EMPLOYMENT AND MIGRATION WORKING PAPERS No. 49

THE LABOUR MARKET INTEGRATION OF IMMIGRANTS IN AUSTRALIA

Thomas Liebig

JEL Classification: J15, J21, J61, J62, J68, J7,J8

JT03222451

Document complet disponible sur OLIS dans son format d'origine

Complete document available on OLIS in its original format 


\title{
DIRECTORATE FOR EMPLOYMENT, LABOUR AND SOCIAL AFFAIRS
}

\author{
http://www.oecd.org/els
}

\section{OECD SOCIAL, EMPLOYMENT AND MIGRATION WORKING PAPERS}

\author{
http://www.oecd.org/els/workingpapers
}

This series is designed to make available to a wider readership selected labour market, social policy and migration studies prepared for use within the OECD. Authorship is usually collective, but principal writers are named. The papers are generally available only in their original language - English or French - with a summary in the other.

Comment on the series is welcome, and should be sent to the Directorate for Employment, Labour and Social Affairs, 2, rue André-Pascal, 75775 PARIS CEDEX 16, France.

The opinions expressed and arguments employed here are the responsibility of the author(s) and do not necessarily reflect those of the OECD

\section{Applications for permission to reproduce or translate all or part of this material should be made to:}

\author{
Head of Publications Service \\ OECD \\ 2, rue André-Pascal \\ 75775 Paris, CEDEX 16 \\ France
}

Copyright OECD 2006 


\section{ACKNOWLEDGEMENTS}

Thomas Liebig is economist in the Non-Member Economies and International Migration Division at the OECD Directorate for Employment, Labour and Social Affairs. This paper is based in part on visits to the key stakeholders in Australia in January 2005.

An earlier draft was discussed at the OECD Working Party on Migration on 2 June 2006. The author wishes to thank all interlocutors during the mission to Australia, as well as members of the Working Party on Migration, for valuable information and fruitful discussions. 


\section{SUMMARY}

1. The labour market integration of immigrants in Australia is shaped by the country's long tradition as an immigration country and its selection policy. Over the post-war period, the main origin countries of immigration to Australia have shifted from English-speaking countries to other OECD countries, and, since the mid-1970s, to non-OECD countries. Parallel to this shift, immigration policy to Australia became increasingly skills focused, which has partly countered the less favourable employment outcomes of migrants from these countries. This increasing selection has resulted in a situation in which the skills structure of the immigrant population, particularly of those from non-OECD countries, is well above that of the native-born.

2. Overall, the labour market integration of immigrant men in Australia can be considered to be relatively favourable in international comparison. This is partly attributable to selection policy and the prevalence of the English language in many parts of the world. Even with similar socio-demographic characteristics, skilled migrants tend to perform better than other migrant groups. In contrast to the positive outcomes for immigrant men, the labour force participation of immigrant women is not high in international comparison.

3. Given the skilled nature of the majority of Australia's immigration intake, it is of particular importance that adequate use is made of the skills of the immigrants. This is not always the case, and overqualification is a problem. With the exception of humanitarian migrants, immigrants do not have access to social security and most labour market services in the first two years after arrival. This may have contributed to increase employment of immigrants, but also aggravated the problem of overqualification, particularly for skilled non-OECD immigrants in the first two years after arrival. There are a variety of measures currently undertaken to tackle this problem. Among these are efforts to increase employersponsored migration and immigration of people with prior Australian qualifications, as well as further streamlining of the recognition of foreign qualifications. The scope for the latter, however, may be limited due to the fact that professions and occupations are not regulated at the national level. Particularly effective in tackling overqualification seem to be temporary and assisted work placements in skilled jobs, but funding for these measures is regional and limited.

4. As all skilled migrants (principal applicants) need job-ready English and many of these also have Australian qualifications and/or a prior job offer, a large part of the immigrant intake can be considered to be partly pre-integrated. This is not the case for immigrants under the humanitarian programme who in turn receive a broad range of integration services to which other migrants do generally not have access. About half of the humanitarian intake is sponsored by individuals and institutions in Australia, who often also provide part of the initial settlement services. These sponsored humanitarian migrants appear to have lower employment probabilities in the long run. The principal integration aid is provided in the form of language training, which is generally open to all immigrants in need of this. In spite of the comprehensive training provided, there is little measurement of its effectiveness with respect to employment. Furthermore, few settlement services are directly targeted at labour market integration.

5. The outcomes of the children of migrants are very favourable in international comparison. This does not only appear to be attributable to the skilled nature of the immigrant intake, but also to the settlement and integration perspective given to all non-temporary immigrants. 


\section{RÉSUMÉ}

6. En Australie, l'intégration des immigrés sur le marché du travail est marquée par la longue tradition du pays en tant que terre d'immigration et par sa politique de sélection. Au lendemain de la guerre, les principaux pays d'origine des immigrants ont changé : les pays anglophones ont cédé la place à d'autres pays de l'OCDE et, depuis le milieu des années 70, à des pays n'appartenant pas à l'Organisation. Parallèlement à cette évolution, la politique australienne d'immigration a privilégié de façon croissante les compétences, ce qui a en partie compensé les médiocres résultats sur le plan de l'emploi qu'enregistraient les immigrés dans leur pays d'origine. Du fait de la rigueur accrue du processus de sélection, l'Australie se trouve maintenant dans une situation où la structure des compétences de la population immigrée, en particulier des individus originaires de pays n’appartenant pas à l'OCDE, est bien supérieure à celle des autochtones.

7. D’après les comparaisons internationales, on peut dire que, globalement, les immigrés de sexe masculin s'intègrent relativement bien sur le marché du travail australien. Cela tient en partie à la politique de sélection pratiquée par l'Australie et à la prévalence de la langue anglaise dans beaucoup de régions du monde. On peut même ajouter qu'à caractéristiques sociodémographiques égales, les migrants qualifiés affichent généralement de meilleures performances que les autres groupes de migrants. Mais les comparaisons internationales montrent que, contrairement aux hommes, les femmes immigrées n'affichent qu'un faible taux d'activité.

8. Comme la majorité des immigrants admis en Australie sont des personnes qualifiées, il est particulièrement important d'utiliser les compétences de cette main-d'œuvre de manière appropriée. Ce n'est pas toujours le cas et la surqualification pose un problème. A l'exception des migrants pour raisons humanitaires, les immigrés n’ont accès ni à la sécurité sociale, ni à la plupart des services liés au marché du travail pendant les deux années suivant leur arrivée dans le pays. Cette disposition a peut-être contribué à augmenter le taux d'emploi des immigrés, mais elle a également aggravé le problème de la surqualification, en particulier pour les immigrés qualifiés ne provenant pas de la zone OCDE, pendant leurs deux premières années de séjour en Australie. Actuellement, une panoplie de mesures sont prises pour remédier à ce problème. On peut notamment citer les efforts visant à accroître les migrations parrainées par les employeurs et l'accueil de personnes ayant obtenu des qualifications en Australie, ainsi que les mesures de simplification de la reconnaissance des qualifications acquises à l'étranger. Toutefois, la portée de ces mesures est probablement limitée du fait que la réglementation en matière de professions et de métiers n'a pas de dimension nationale. Une mesure semble particulièrement efficace pour remédier au problème de la surqualification, à savoir le placement temporaire avec mesures d'accompagnement, permettant aux immigrés d'occuper des emplois qualifiés; mais le financement de cette mesure, qui s’effectue au niveau régional, est limité.

9. Comme tous les migrants qualifiés (demandeurs principaux) doivent posséder un niveau d'anglais suffisant pour travailler et comme nombre d'entre eux possèdent déjà des qualifications australiennes et/ou une offre d'emploi préalable, une grande partie des immigrants admis peuvent être considérés comme partiellement " pré-intégrés ». Ce n’est pas le cas des immigrants arrivant au titre du programme humanitaire qui, pour leur part, bénéficient d'une large palette de services d'intégration auxquels les autres migrants n’ont généralement pas accès. Environ la moitié des immigrants pour raisons humanitaires admis en Australie sont parrainés par des individus ou des institutions qui leur offrent souvent une partie des services initiaux d'installation. Il semble qu'à terme, les probabilités d'emploi de ces migrants parrainés soient moindres. La principale forme d'aide à l'intégration est la formation à l'anglais dont peuvent généralement bénéficier tous les immigrants qui en ont besoin. Mais en dépit du caractère 
exhaustif de la formation dispensée, son efficacité du point de vue de l'emploi est rarement mesurée. En outre, peu de services d'installation ciblent directement l'intégration sur le marché du travail.

10. Les résultats affichés par les enfants de migrants sont très positifs comparés à ceux que l'on observe dans d'autres pays. Il semble que cela ne tienne pas uniquement à l'accueil d'immigrants qualifiés mais aussi aux perspectives d'installation et d'intégration offertes à tous les immigrés autres que temporaires. 


\section{TABLE OF CONTENTS}

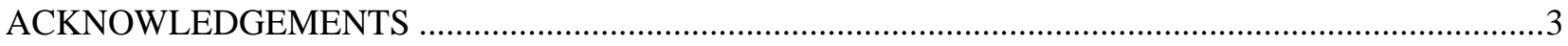

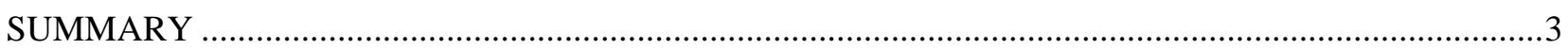

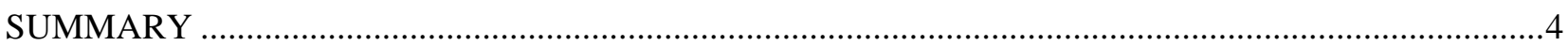

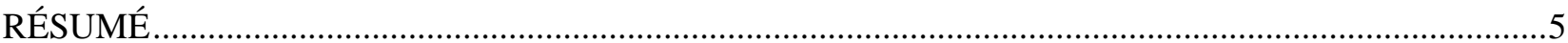

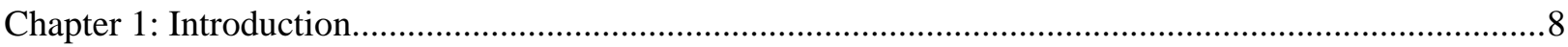

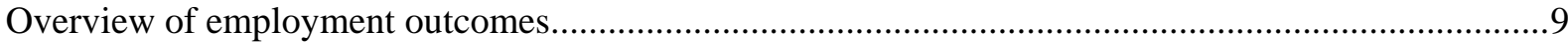

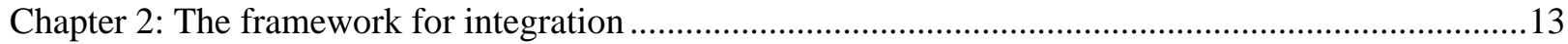

The evolution of Australia as a multicultural immigration country ....................................................13

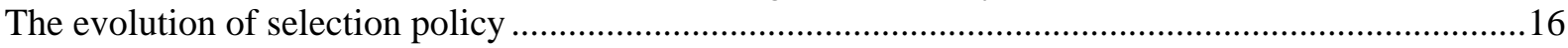

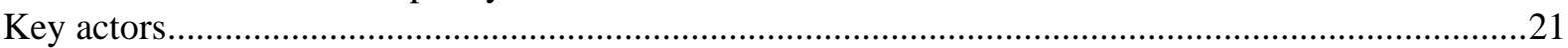

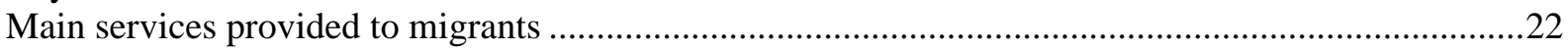

Chapter 3: Key issues in the labour market integration of immigrants..............................................26

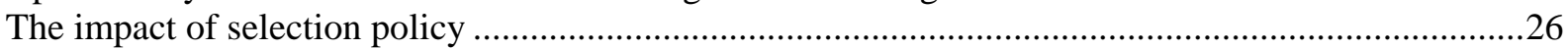

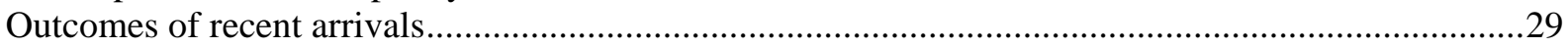

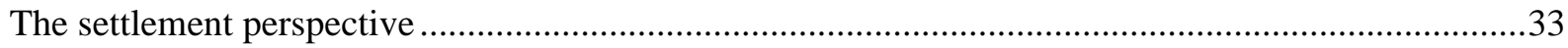

The recognition of foreign qualifications and experience .........................................................................33

The impact of the waiting period on labour market outcomes ...............................................................38

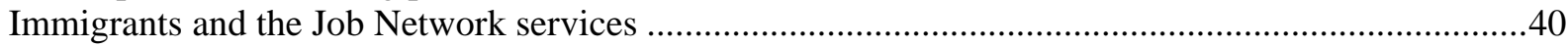

Importance of English language and effectiveness of language training .............................................41

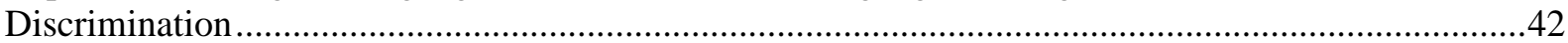

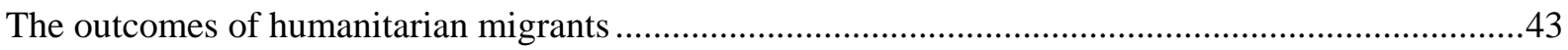

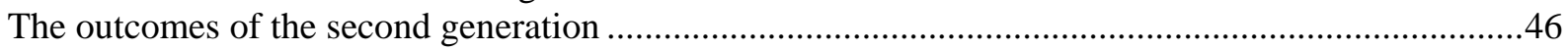

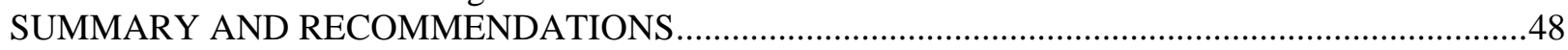

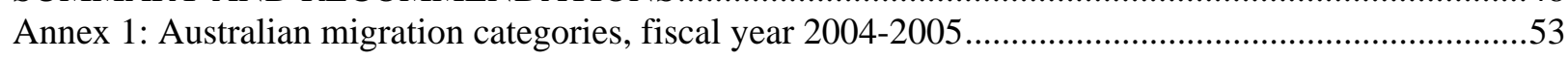

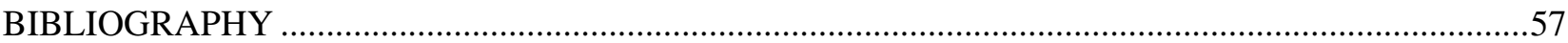




\section{THE LABOUR MARKET INTEGRATION OF IMMIGRANTS IN AUSTRALIA}

\section{Chapter 1: Introduction}

11. The Australian situation with respect to the integration of immigrants is a rather unique one. It differs from that of the other OECD countries that are participating in this first round of country reviews (Sweden, Germany, France, and Denmark) in several important ways. Australia is a country of immigration par excellence. It has been settled by immigrants, and immigration is considered part of the national heritage. For decades, there has been a comparatively large public consensus on the importance and need for immigration and, as a consequence, integration. The economy is strongly dependent on immigrants, and about $25 \%$ of the workforce are foreign-born.

12. Another distinguishing fact is that Australia admits many highly-skilled migrants and it does this by a procedure of selection by the national administration (as opposed to employers) on the basis of a variety of factors which are generally seen as facilitating integration. Australia has a long experience of such migration management, and a sophisticated selection policy has evolved as an outcome of this experience. Finally, Australia's national language is widely spoken across the world, and many migrants can thus be expected to master the language prior to arrival.

13. Given the context outlined above, labour market outcomes of immigrants in Australia are generally viewed as being positive, and a first glance at the data bears this out. As will be seen below, this is partly attributable to selection policy, but a variety of other factors also play a role. It is also important to note that the integration process does have some problems.

14. The target population considered in this report is the foreign-born population. This study will limit itself to integration into the labour market. This is not to imply that these are the only outcomes which matter, as clearly they are not, but is adopted to limit the scope of the study to manageable proportions. In addition, if integration into the labour market does not necessarily guarantee social integration, it is certainly a major step with respect to immigrants' being able to function as autonomous citizens in the host country and to ensure both acceptance of immigration by the host-country population and the sustainability of migration policy over the long term. 
15. The remainder of this report is structured as follows. After a brief overview of some of the key employment outcomes of immigrants in Australia, the framework for integration is presented in Chapter II. This encompasses the history of migration and integration in Australia; the main migrant groups and their characteristics; the development of selection policy; and an overview of the key integration instruments and the actors involved. On this basis, some issues which are particularly pertinent in the Australian context are analysed in Chapter III. This includes the impact of selection policy and the recognition of foreign qualifications and the integration of highly skilled migrants on the one side, and of humanitarian migrants on the other side. The report ends with an overall summary including recommendations.

\section{Overview of employment outcomes}

16. Employment rates ${ }^{1}$ for male immigrants are only exceeded by those of immigrants in the United States and Canada (Table 1). Australia is the country with the lowest unemployment rates of immigrants in the comparison group - both in absolute terms and compared to the native-born. ${ }^{2}$ Somewhat less favourable, however, are the employment rates of immigrant women, which are both in absolute and relative terms close to those observed in European countries such as Sweden and the United Kingdom. Since unemployment is also low, immigrant women's participation in the labour market is not very high in international comparison, particularly with respect to immigrant women from non-English-speaking OECD countries. This is, however, partly attributable to the large numbers of women from Southern Europe, where labour market participation is generally low. Furthermore, immigrants from non-English-speaking OECD countries are significantly older on average than the other groups, which is associated with lower labour market participation.

1. The term employment rate is used in this report synonymously with the employment-population ratio. It is not the ratio of persons employed to persons in the labour force.

2. In this context, it should also be noted that the incidence of long-term unemployment in Australia is lower among the foreign-born than among the native-born - in contrast to what is observed in most European OECD countries. 
Table 1: Labour force characteristics of the native- and foreign-born populations, 15-64 years old, selected OECD countries, 2004

\begin{tabular}{|c|c|c|c|c|c|c|c|}
\hline & \multicolumn{2}{|c|}{ Participation rate } & \multicolumn{2}{|c|}{ Employment rate } & \multicolumn{3}{|c|}{ Unemployment rate } \\
\hline & $\begin{array}{c}\text { Native- } \\
\text { born }\end{array}$ & $\begin{array}{l}\text { Foreign- } \\
\text { born }\end{array}$ & $\begin{array}{c}\text { Native- } \\
\text { born }\end{array}$ & $\begin{array}{c}\text { Foreign- } \\
\text { born }\end{array}$ & $\begin{array}{c}\text { Native- } \\
\text { born }\end{array}$ & $\begin{array}{l}\text { Foreign- } \\
\text { born }\end{array}$ & Ratio \\
\hline Men & & & & & & & \\
\hline Australia & 85.3 & 79.9 & 80.5 & 75.5 & 5.6 & 5.5 & 1.0 \\
\hline $\begin{array}{l}\text { - OECD English- } \\
\text { speaking }\end{array}$ & & 87.2 & & 83.4 & & 4.3 & 0.8 \\
\hline $\begin{array}{l}\text { - - OECD Non- } \\
\text { English-speaking }\end{array}$ & & 75.6 & & 72.7 & & 3.8 & 0.7 \\
\hline -- Non-OECD & & 77.5 & & 72.0 & & 7.1 & 1.3 \\
\hline Canada & 83.2 & 83.2 & 78.6 & 77.7 & 5.5 & 6.6 & 1.2 \\
\hline Denmark & 85.1 & 74.1 & 81.4 & 63.4 & 4.4 & 14.4 & 3.3 \\
\hline France & 75.1 & 77.5 & 69.1 & 67.0 & 8.0 & 13.6 & 1.7 \\
\hline Germany & 79.2 & 78.8 & 71.0 & 64.4 & 10.3 & 18.3 & 1.8 \\
\hline Netherlands & 85.0 & 76.3 & 81.9 & 68.4 & 3.6 & 10.3 & 2.9 \\
\hline Sweden & 80.7 & 74.6 & 75.7 & 64.2 & 6.2 & 13.9 & 2.3 \\
\hline United Kingdom & 82.0 & 78.5 & 78.1 & 72.8 & 4.7 & 7.3 & 1.5 \\
\hline United States & 78.4 & 85.2 & 73.0 & 80.2 & 6.9 & 5.8 & 0.8 \\
\hline Women & & & & & & & \\
\hline $\begin{array}{l}\text { Australia } \\
- \text { - OECD English- }\end{array}$ & 69.9 & 60.4 & 65.9 & 57.0 & 5.7 & 5.6 & 1.0 \\
\hline $\begin{array}{l}\text { speaking } \\
\text { - - OECD Non- }\end{array}$ & & 70.0 & & 67.0 & & 4.3 & 0.8 \\
\hline $\begin{array}{l}\text { - - OECD Non- } \\
\text { English-speaking }\end{array}$ & & 51.5 & & 49.7 & & 3.5 & 0.6 \\
\hline -- Non-OECD & & 58.2 & & 54.0 & & 7.2 & 1.3 \\
\hline Canada & 72.5 & 68.9 & 68.9 & 64.2 & 4.9 & 6.8 & 1.4 \\
\hline Denmark & 77.4 & 61.9 & 73.4 & 55.5 & 5.2 & 10.3 & 2.0 \\
\hline France & 64.5 & 58.2 & 58.1 & 48.2 & 9.9 & 17.2 & 1.7 \\
\hline Germany & 66.9 & 55.0 & 60.5 & 46.6 & 9.6 & 15.2 & 1.6 \\
\hline Netherlands & 71.2 & 56.0 & 68.1 & 50.1 & 4.3 & 10.6 & 2.5 \\
\hline Sweden & 76.9 & 68.5 & 72.9 & 60.1 & 5.2 & 12.2 & 2.3 \\
\hline United Kingdom & 69.6 & 59.3 & 66.9 & 55.0 & 3.9 & 7.3 & 1.9 \\
\hline United States & 69.2 & 60.3 & 65.4 & 56.2 & 5.5 & 6.8 & 1.2 \\
\hline
\end{tabular}

Note: OECD English-speaking includes the United Kingdom, New Zealand, Canada, Ireland and the United States.

Source: European Community Labour Force Survey, except for Australia (Survey of Education and Work) and Canada (Survey of Labour and Income Dynamics). Data refer to 2002 for Canada. 
17. For both genders, immigrants from English-speaking OECD countries have even higher employment rates than native-born Australians. There is little difference, however, between immigrants from other OECD countries and those from non-OECD countries. As will be seen below, this pattern of more favourable outcomes for immigrants from English-speaking OECD countries vis-à-vis other immigrants is also observed with respect to other indicators of labour market integration. Furthermore, it also holds after controlling for socio-demographic characteristics and years of residence. This explains why Australian statistics (e.g. on labour market instruments, see below) tend to focus on the labour market characteristics of immigrants from non-English-speaking countries relative to the native-born, since they are the migrant group that is of policy interest. These figures, however, present a downwardly biased picture if interpreted as the outcomes for the immigrant population as a whole.

18. Immigrants from non-English-speaking countries, and from non-OECD countries in particular, account for a growing part of the immigrant stock. ${ }^{3}$ Australia has tried to counter this linguistic disadvantage, in particular in the past decade, by stronger selection policies that include a requirement of work-ready English, and a shift towards recruitment of people with Australian qualifications (i.e. mainly graduates from Australian universities, see below).

19. Nevertheless, gaps between the employment rates of immigrants and those of the native-born have grown slightly for both genders, notably for women since the beginning of the 1990s. Yet, these changes are not large (see Figures 1a and 1b), ${ }^{4}$ in comparison with those observed e.g. in Germany and Sweden (OECD 2004 and OECD 2005b). Thus, despite the stronger selection of immigrants since the mid1990s (see below), the gaps in the employment rates of immigrants vis-à-vis the native-born have not declined - which is partly attributable to the weight of the overall immigrant stock relative to the new arrivals. Furthermore, only part of the new arrivals (i.e. principal applicants under the skills stream of the migration programme) have been directly subjected to the stronger selection criteria. As will be seen below, for this group labour market outcomes have improved markedly.

3. At the 2001 census, more than $54 \%$ of all foreign-born were from non-OECD countries, and a further $16 \%$ were from non-English-speaking OECD countries.

4. Indeed, since 1994 the gaps have remained broadly constant for both genders. Unfortunately, with publicly available data, a further disaggregation into the three main country-of-origin groups (OECD-Englishpeaking, OECD-non-English-speaking, non-OECD) is not possible. 
Figure 1a: Evolution of employment-population ratios of foreign- and native-born in Australia, 15-64, men

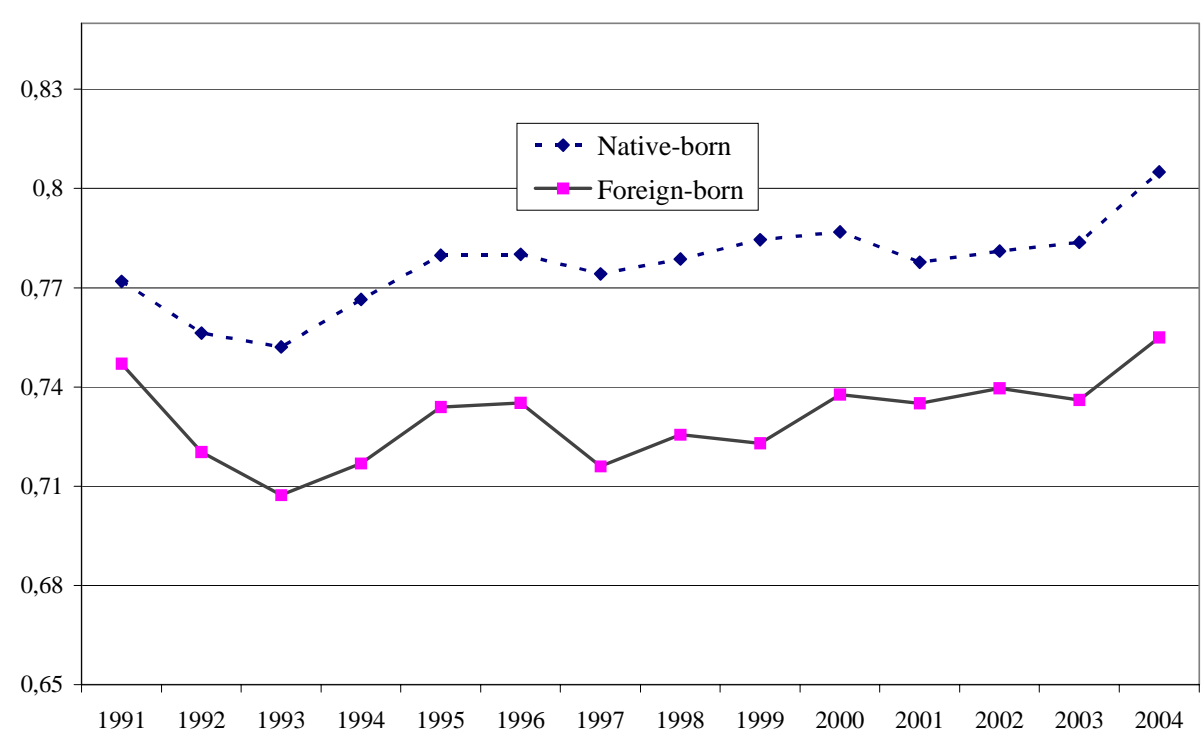

Source: Calculations based on Data from the Australian Bureau of Statistics.

Figure 1b: Evolution of employment-population ratios of foreign- and native-born in Australia, 15-64, women

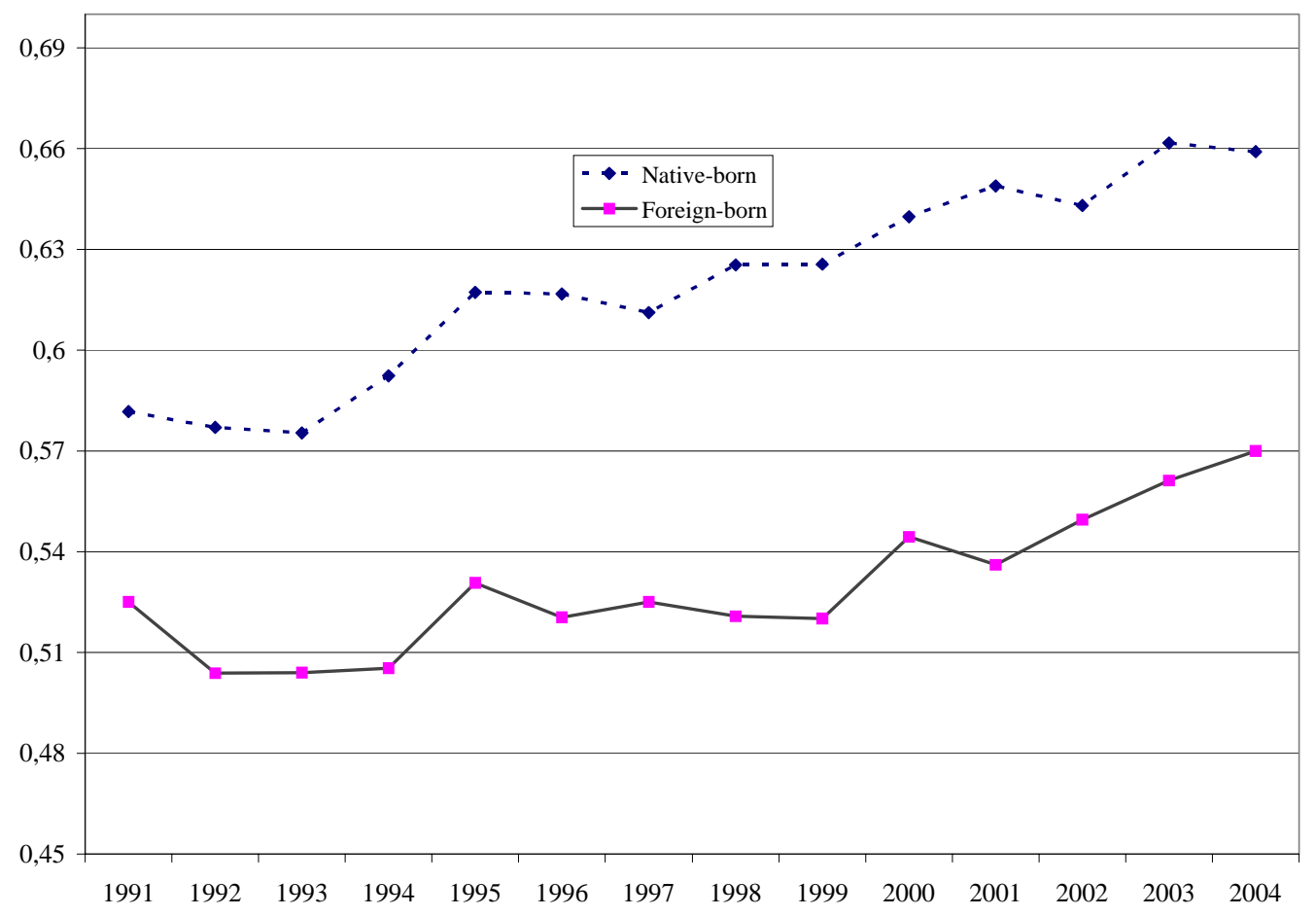

Source: Calculations based on Data from the Australian Bureau of Statistics. 


\section{Chapter 2: The framework for integration}

\section{The evolution of Australia as a multicultural immigration country}

20. Since the first establishment of penal colonies in 1788 and free settlers shortly later, Australia has been a country of immigration, and almost half of the population has some migration background, that is, are either immigrants or descendants of immigrants. ${ }^{5}$ In the early years, settlers came almost exclusively from the United Kingdom and Ireland. During Australia's gold rush in the 1850s, immigration from Asia increased massively, and Chinese miners accounted for a growing part of the population. The resulting diversification of the migrant inflow, but also fears of competition for jobs by Asians, led to rising tensions. These conflicts and an emerging nationalism resulted in the implementation of the Immigration Restriction Act in 1901, which virtually excluded non-European migrants (see DIMIA 2003b). At that time, $23 \%$ of the population was foreign-born. Following the introduction of this so-called "White Australia” policy, the Great Depression and the two World Wars, the share of immigrants in the total population fell by more than fifty per cent until the end of World War II, when the foreign-born accounted for only about $10 \%$ of the population.

21. The decline in the immigrant population, low birthrates and strong labour demand led to a more pro-active settlement policy. In 1945, the predecessor of today's Department of Immigration and Multicultural Affairs (DIMA) was established to encourage and assist migration to Australia. ${ }^{6}$ The government set an annual net immigration target of $1 \%$ of the resident population. The principal focus still remained the United Kingdom, but formal immigration agreements, assisted passage schemes and combinations of the latter two were also established with a variety of other western European countries, former Yugoslavia, and Turkey. In July 1947, Australia also concluded an agreement with the newlyestablished International Refugee Organisation (the predecessor of today's UNHCR) to select and admit annually at least 12000 displaced persons from refugee camps in Eastern Europe. Although Australia had been admitting refugees since its foundation, this was the first formal (humanitarian) resettlement programme and centered around a framework of mutual obligations. The resettlers were required to work for a period of two years under the supervision of the Australian government. In turn, they received a limited range of settlement services, including accommodation and basic English-language training (York 2003). ${ }^{7}$ This language training for immigrants was among the first of its kind in the world.

22. The post-war period until the mid-1960s was shaped by a policy coined as "assimilation", under which new arrivals were expected to become rapidly indistinguishable from the native-born population (DIMIA 2003b). Since 1966, and consistent with the notion of "assimilation", applications for settlement were judged on the basic of ability to integrate readily (DIMIA 2001).

23. Along with assimilation policy, pro-active naturalisation emerged as one of the defining elements of Australian integration policy. The first citizenship ceremony was held on Australia's National Day (January 26) in $1949 .^{8}$ Still today, citizenship ceremonies are held widely across Australia on that holiday, celebrating the contribution of migrants to Australia. Initially, citizenship law mirrored the so-called "White Australia” policy. Only after 1957 did non-Europeans gain gradual access to Australian citizenship.

5. About $23 \%$ of the population are foreign-born, and at the 2001 census the share of the native-born population that had at least one parent who is foreign-born was $20 \%$.

6. Until January 2006, the Department was also in charge of Indigenous Affairs and was then named DIMIA.

7. Indeed, there is a striking continuity in the scale and scope of the humanitarian resettlement programme since then (see below).

8. Before that date, the status of Australian citizen did not exist since all citizens of countries of the Commonwealth were deemed to be British. 
Currently, Australia has the most liberal provision for naturalisation with respect to years-of-residence requirements in the OECD. Citizenship can be acquired after two years of settlement and is actively encouraged by the authorities. This stands in notable contrast to the European countries, where naturalisation requires a more lengthy stay in the host country and is seen in some countries as the culmination of successful integration.

24. The more active recruitment and settlement policy since 1947 had a profound impact on the growth of the migrant population and the country-of-origin composition. The annual settler intake rapidly increased from 34000 in 1947 to 184000 in 1950, and the total immigrant population grew from 744000 in 1947 to almost 1.8 million in $1961 .{ }^{9}$ The bulk of this growth was attributable to immigrants from outside the OECD English-speaking countries (UK, Ireland, USA, New Zealand), whose share increased from $20 \%$ to well above $50 \%$ of the stock of the foreign-born during that period (see Figure 2).

25. In the late 1960s, the "White Australia" admission policy and its integration counterpart, the "assimilation policy", became incompatible with Australia's trade and foreign policy, which implied an increasing orientation toward the newly independent and emerging economies on the Asian continent (Jupp 1995). Indeed, as trade with Asia developed in the 1960s, there was concern about a lack of knowledge on the region, with few residents being able to speak an Asian language (Auchmuty 1970) ${ }^{10}$ Furthermore, the favourable economic development in the traditional source countries in Europe was expected to result in a decline in the migration flow from that region (Ingram 2003).

Figure 2: Characteristics of the immigrant population (in thousands) since 1947

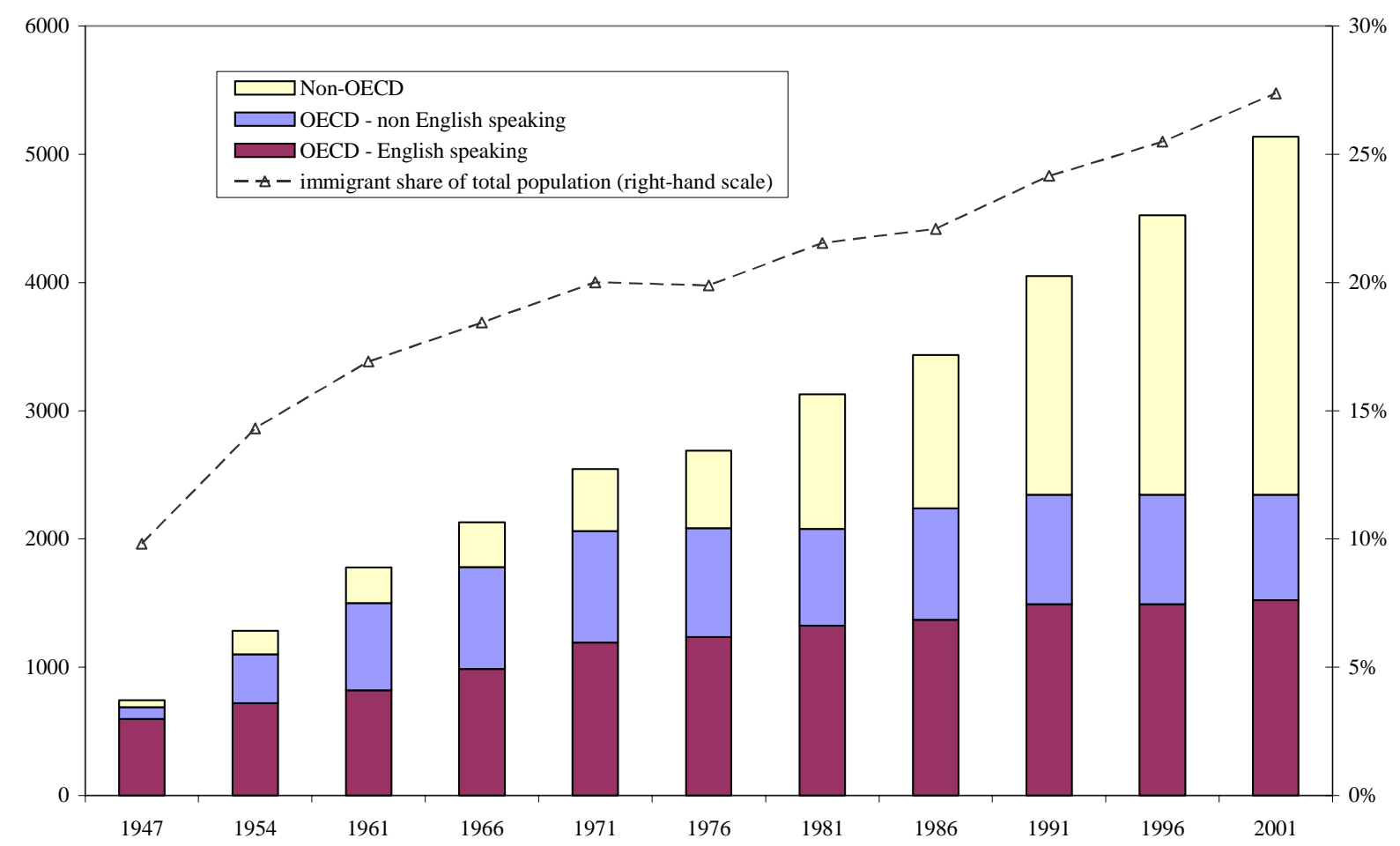

Source: Calculations based on Australian Census Data.

9. With few exceptions, the annual gross intake of permanent immigrants has varied between 70000 and 170000 since 1950 .

10. Currently, about half of Australia's trade is with East Asia. 
26. The "White Australia" policy was formally renounced in 1973. The new non-discriminatory policy passed its first major test in 1975, when refugee crises in East Timor and Vietnam led to a substantial inflow of refugees with an Asian background. Under the new integration philosophy of the 1970s that is now being referred to as the "integration period", immigrants were supposed to become part of Australia without necessarily abandoning their ethnic identity. One important result of this new policy was the 1975 Racial Discrimination Act that prohibited discrimination based on ethnic origin.

27. The growing diversity of the migrant intake also fostered an expansion of government services provided to migrants. A committee for the recognition of overseas professional qualifications was founded in 1969. Since 1969, the Adult English Migrant Programme (AMEP) has been provided in the form of fulltime intensive courses with the explicit aim to provide adequate English for employment. The Telephone Interpreter Service that provides free interpretation assistance was initiated in 1973, and a Home Tutor Scheme to teach migrants with particular difficulties at home was launched in 1974.

28. In the course of the 1970s, integration policy shifted towards a stronger emphasis on maintenance of the immigrants' cultural roots, while at the same time assuring equal opportunity and equal access to government programmes and services. This policy is now generally referred to as "multiculturalism". Integration policy since then has been targeted at a better provision for migrants needs within the mainstream programmes. Supplementary support was largely confined to the ethnic communities who, in turn, received government funding. This development was fostered inter alia by the creation of Migrant Resource Centres (MRCs), which aim at facilitating self-support activities of migrants in the local communities.

29. The concept of multiculturalism is the formal acknowledgement of the ethnic and cultural diversity of Australia. The main principles were outlined in the 1989 National Agenda for a multicultural Australia (DIMIA 1989), but were updated and renewed in 2003 in the policy statement Multicultural Australia: Unified in Diversity (DIMIA 2003a). In this statement, multiculturalism is not only defined in terms of individual cultural identity and equality of treatment and opportunity, but also with respect to economic efficiency, i.e. "the need to maintain and utilise effectively the skills and talents of all Australians, regardless of background". Indeed, since then, there seems to be a growing emphasis on the beneficial contribution of the multicultural population structure to the economy, as well as the balance between the individuality and unity of the rights and responsibilities of people in Australia. As part of the regular policy cycle, the government is currently revising this policy to meet the challenges and benefits of a non-discriminatory migration policy.

30. Since the late 1970s, immigration policy gradually began to develop in a bifurcated way. On the one hand, it became more selective and skills-focused. Parallel to this increasing emphasis on selection, a genuine and ongoing refugee policy evolved, which was formally announced in 1977 for the first time. Since then, humanitarian resettlement has been seen as a clearly separate component of the overall migration programme, to be supported by specialized services targeted at such resettlers. These services are discussed in further detail below.

31. The policy with respect to humanitarian immigration is based on annual numerical limits, which are currently set at 13000 per year. 6000 of these places are attributed to refugees. Both in absolute and per capita terms, the Australian humanitarian resettlement programme is among the largest in the OECD. ${ }^{11}$ Since 1981, there has been a Global Special Humanitarian Programme (SHP). The immigrants under this programme do not formally meet the United Nation's refugee definition but experienced substantial

11. However, in many other OECD countries - including those who also accept resettlers - there is substantial humanitarian immigration by other means, i.e. through asylum-seeking. This stands in contrast to Australia, where asylum seeking is relatively low. 
discrimination amounting to gross violations of human rights in their home country. The allocation between the different categories ${ }^{12}$ in the humanitarian programme works as follows: those places not attributed to refugees under the UN Convention are for onshore humanitarian migrants (i.e. recognised asylum-seekers and people in need of protection) and SHP migrants, with places not taken by the onshore programme being transferred to the SHP. Since the onshore/protection component is small -1082 individuals in 2004/05 - in effect about half of the programme is for the SHP. Migrants under this programme are sponsored by a resident or an institution in Australia who proposes them to DIMA and assists in the settlement of the migrants concerned. ${ }^{13}$

32. The source countries of the humanitarian intake have changed substantially over time. From the 1970s to the early 1990s, most of the refugees were from Vietnam, Chile, Lebanon and Cambodia, with the Vietnamese accounting for the largest share. In the mid-1990s, individuals from one of the successor countries of the Former Federal Republic of Yugoslavia and from Iraq and Afghanistan were most prominent in the humanitarian programme. Most recently, the Sudanese have emerged as the most important group with respect to annual resettlement figures. There is often a fortunate conjunction between the fact that some humanitarian migrants are from rural areas themselves and the existence of rural labour shortages in Australia. Correspondingly, a small but growing proportion of humanitarian migrants are placed in rural Australia. This is, however, not the case for SHP migrants, who have generally received accommodation by their proposers. These migrants are concentrated in the two most populous States, New South Wales and Victoria.

\section{The evolution of selection policy}

33. About one third of the current immigrant flows are on the basis of family links. Until the mid1990s, the various forms of family-linked migration accounted for the majority of permanent immigration. Since then, there has been an increase in the total number of skill-stream migrants, reflecting an increased emphasis on skilled migrants within an expanded programme. Skilled migrants and their accompanying family now account for the majority of the intake (see Figure 3 below). ${ }^{14}$ Indeed, the most profound changes in Australia's immigration policy over the past decades concerned the selection of skilled migrants. Applications for settlement were partly judged on the basis of a potential migrant's qualifications already since 1966. Since then, immigration policy has become increasingly skills-focused. Indeed,

12. Humanitarian migrants encompass mainly resettlers (i.e. refugees and SHP migrants, both of which are offshore - with a few exceptions regarding the SHP) and accepted asylum seekers (i.e. onshore migrants). See Annex 1 for details.

13. In a somewhat more informal way, refugees had already been admitted prior to this programme on the basis of links to residents in Australia. For example, following the 1976 Civil War in Lebanon, visas were granted to Lebanese suffering from war-related hardship and who were relatives of Australian residents, provided they met certain health and character requirements (York 2003).

14. The decline in the relative importance of family reunion is to some degree attributable to changes in the classification of the family reunification visa. Until 1997, for example, the immediate family of humanitarian migrants was included in the family stream. Since then, they are included in the Humanitarian Programme. There is a trade-off involved in this: on the one hand, by including the family in the Humanitarian Programme, these individuals are entitled to substantial integration support (see below). On the other hand, including the family members of humanitarian migrants has reduced the number of places available to other refugees. In this context, it should also be noted that the points-tested Concessional Family category (i.e. selected and sponsored non-dependent children, parents of working age, brothers, sisters, nieces and nephews) was moved to the Skill Stream in 1997 and renamed SkilledAustralian linked (since 1999: Skilled-Australian sponsored). These changes were associated with stronger selection criteria for that group, and they are now subject to the same threshold requirements as the Skilled Independent category (see below). 
immigrant cohorts who have arrived since the mid-1970s have a higher educational attainment than the native-born, and this favourable trend seems to have accelerated over time (see Table 2). ${ }^{15}$

Table 2: Percent of highly-qualified foreign-born population by year of arrival, 25-64 years old, 2004

\begin{tabular}{|c|c|}
\hline Year of arrival & $\begin{array}{c}\text { Percent highly- } \\
\text { qualified }\end{array}$ \\
\hline 1970 and before & $25 \%$ \\
\hline 1971-1975 & $30 \%$ \\
\hline $1976-1980$ & $35 \%$ \\
\hline 1981-1985 & $32 \%$ \\
\hline $1986-1990$ & $52 \%$ \\
\hline 1991-1995 & $47 \%$ \\
\hline since 1996 & $56 \%$ \\
\hline Total foreign-born & $38 \%$ \\
\hline Native-born & $32 \%$ \\
\hline
\end{tabular}

Note: Highly-qualified is defined as having a diploma or above.

Source: Calculations based on the Household, Income and Labour Dynamics in Australia Survey.

34. In 1979, a first points test was introduced - the "Numerical Multifactor Assessment System", giving weight to occupational and language skills, but also to family ties with Australians, as indicators of the probability of successful settlement (DIMIA 2001). In 1982, a new selection system came into force which reinforced this tendency. Under such a system, qualifications and characteristics of potential migrants are translated into a certain amount of points. In order to be accepted, an individual has to pass a certain threshold number of points to be accepted as an immigrant; the threshold is set by the government.

35. Research in the late 1980s and in the course of the 1990s suggested substantial and growing disadvantages for migrants who did not come from the English-speaking OECD countries, and lack of an appropriate level of English and the recognition of overseas skills were prominent among the identified obstacles (see the overview in Hawthorne 2005). ${ }^{16}$ This tendency was deemed particularly worrisome since the majority of new migrants came from non-English-speaking countries. Australia has tried to counter this by increasing skilled migration (both in absolute and relative terms), accompanied by a variety of changes to the migrant selection which have resulted in a more stringent selection, in particular with respect to English skills, along with the favouring of Australian qualifications and mandatory pre-assessment of overseas qualifications.

15. These figures are only indirect evidence since those who have subsequently left Australia again (about one quarter of the total intake) are not included. On the whole, however, the picture is probably close to the actual intake, as those who left would have to be very different to have a big impact.

16. The distinction between English-speaking and non-English-speaking countries is not always unambiguous. DIMA classifies the source countries into four English Proficiency groups. The first group - referred to as the "main English-speaking countries" includes the United Kingdom, Ireland, Canada, the United States, South Africa and Zimbabwe (see DIMIA 2003, Chapter 6 for details). Immigrants from New Zealand are apart from the Migration Programme and thus excluded from this formal classification, but otherwise included in general references to English-speaking migrants. Non-English-speaking countries are the remainder, encompassing countries like India where English is an associated official language. In recent publications, this group is often referred to as CALD (culturally and linguistically diverse). 
36. Originally, Australia's immigration legislation was largely based on ministerial discretion. The selection criteria were not specified and the government could thus easily change them, which, as a result, happened rather frequently. The large scope for discretion led to a situation in which many denied onshore applications were successfully challenged by appeal or in court (Betts 2003). That situation changed with the 1989 Immigration Amendment Act, which established clearer rules and selection criteria. At that occasion, the overall immigration programme was formally divided into three main components - a family stream, a skilled migrant stream and a humanitarian stream (which was separated from the overall programme in 1993). This change was also associated with a larger skills component. Since the mid-1990s, the skill stream has grown markedly, both in absolute and relative terms - from $41 \%$ of the total intake in $1996 / 97$ to $58 \%$ in 2004/05 (Figure 3).

37. Nevertheless, the proportion directly selected on the basis of skills - i.e. the principal applicants in the skilled migrant programme - is still below $30 \%$ of total immigration. However, to the extent that persons tend to marry people of the same educational attainment and that there tends to be a high correlation between the educational attainment of parents and that of their children, the impact of the selection is much greater. One indication of this observation is that those migrating in the family stream are also relatively skilled. Data from DIMA on employment and occupation prior to arrival show that about one third of the migrants entering in the family category were employed in skilled occupations before entering Australia.

Figure 3: Evolution of Australia's migration programme outcomes (incl. humanitarian programme) since financial year 1990/1991

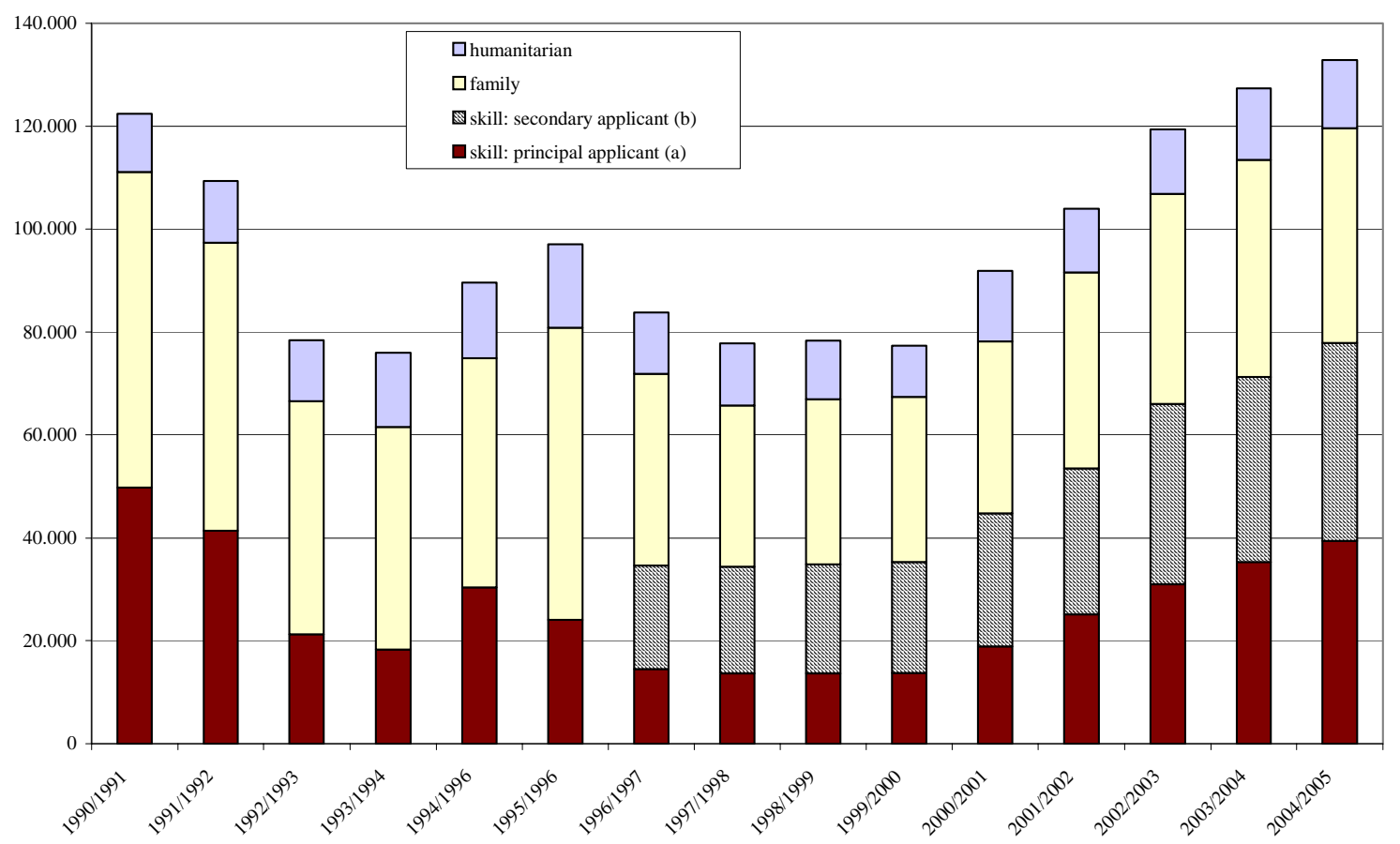

Note: (a) Prior to 1996/97, secondary applicants are included in the principal applicant numbers. Since that year, the Concessional Family (i.e. sponsored extended family of skilled migrants) is furthermore recorded in the skill stream rather than in the family stream. (b) Secondary applicants are family members of the principal applicant. This includes spouses and de facto spouses, dependent children and other single dependent relatives.

Source: DIMA. 
38. As mentioned above, skilled immigration not only grew over the 1990s, but admission of skilled migrants also became more selective. In 1993, pre-migration English-language testing was introduced for a broad variety of occupations, and selection policy has been tightened further in subsequent years. Currently, pre-migration English testing as well as prior qualifications assessment are required for all principal applicants under the skills stream. There are certain core threshold requirements which all principal applicants intending to enter Australia as migrants under the general skilled migration scheme have to meet. These are: $i$ ) age below 45 at the time of application; ii) vocational English; iii) skills assessment; iv) an occupation on the skilled occupation list; and $v$ ) recent skilled work experience (except for students with Australian qualifications, see below). "Vocational" English basically means sufficient English to be able to work in Australia. Immigrants have to prove this knowledge by certain minimum scores in speaking, reading, listening, and writing. In some occupations, higher English levels are required.

39. Additional points are now also awarded to migrants whose skills are in particular demand and to those whose spouses are considered to be skilled as well. There are concessional criteria applying to skilled migrants who are sponsored by relatives (within defined degrees of relationships) who are Australian citizens or permanent residents. In addition, people willing to settle in defined regional or lower growth areas of Australia also benefit from concessional requirements - they need only 100 instead of 120 points in the points system.

40. More than $15 \%$ of the skilled migrants are employer-sponsored, i.e. they have a job offer prior to immigration (for a description of the current migration categories and their quantitative importance see Annex 1), and it is an objective of the government to increase such employer-sponsored migration since these individuals are automatically integrated into the labour market upon arrival. ${ }^{17}$ Migrants entering Australia under the Employer Nomination Scheme - i.e. skilled immigrants who immigrate on the basis of a work offer in a skilled job - also have to meet the above-mentioned core threshold requirements, unless special circumstances apply. Furthermore, there are certain minimum wage and occupational requirements to be met. The thresholds for employer-sponsored migration are somewhat lower for non-metropolitan areas. There are a variety of restrictions on employer-sponsored migration. For example, the occupation must be mentioned on the Employer Nomination Skilled Occupation List, which, among others, includes occupations in shortage.

41. A substantial part of the current immigrant intake is onshore, that is, it consists of individuals who were already in Australia at the time of the application for the visa that enables permanent residence. This is notably the case for students. Indeed, the above-mentioned shift towards migration of people with Australian qualifications is the result of the introduction of a pathway in 2001 by which international students could remain in Australia on successful completion of their studies and apply for general skilled migration visas. ${ }^{18}$ Australia currently has the highest share of foreign students in tertiary education enrolment among OECD countries, and a significant number of these become permanent immigrants after graduation. These immigrants may also achieve additional points in the Australian points system. In addition, they get a waiver for the work-experience requirement under certain conditions. More than 50\% of the current immigrant intake under the General Skilled Migration stream has Australian qualifications. However, foreign students with a scholarship from the Australian government (AusAID recipients) and overseas-government-sponsored students are unable to apply for a skilled migration visa for at least two years after completing their studies.

17. Increasing employer-sponsored immigration is one objective of the Skilled Migrant Expos, at which Australian employers get in contact with skilled people interested in migrating to Australia. Such Expos were inter alia held in some major European cities in 2005.

18. Previously, such students generally had to leave Australia before they could apply for a visa for permanent residence. 
42. The fact that a substantial part of the migrant intake is now selected on the basis of their skills and their economic contribution to Australia undoubtedly helps to ensure public acceptance of the refugee policy. Public acceptance of the migration policy may also be helped by the requirement that skilled and family migrants be generally self-supporting for the first two years in Australia: In 1997, a waiting period for immigrants' eligibility for social security income support payments was increased from six months to two years. In addition, immigrants in the skilled and family stream who lack a vocational English level pay a higher upfront visa fee, which in turn entitles them to free language training. Since July 2002, all family reunion migrants need sponsors who undertake to support them for the first two years in Australia, including accommodation and financial assistance, where required. Furthermore, most labour market services are available only to those in receipt of government income support and who are unemployed. Therefore, these two main immigrant categories do generally not have access to most labour market services, with the exception of job matching. In contrast, migrants accepted under the humanitarian programme not only have full access to social security and all labour market services upon arrival, but are also eligible for a broad range of specialised settlement services. These will be discussed in some more detail in the next section.

43. With respect to the immigrant stocks, visa data suggests that around $50 \%$ of the immigrant stock are in the family category, and about $12 \%$ are humanitarian immigrants. ${ }^{19}$

44. In addition to the three categories of permanent settlers (skilled migrants, family migrants, and the humanitarian programme), Australia has had unrestricted movement with New Zealand. Since the 1920s, there has been virtually unrestricted movement of people between Australia and New Zealand under various reciprocal entry arrangements. ${ }^{20}$ More than 400000 residents (9\% of the foreign-born population) in 2003 were born in New Zealand, placing it as the second most important origin country after the United Kingdom (about 1.1 million or $24 \%$ of the foreign-born - see Table 3).

19. This assumes that re-migration is proportional to the numbers in each category. However, it is believed that humanitarian migrants are less likely to re-migrate. Thereby, their actual share could be higher.

20. In 1973, the Trans-Tasman Travel arrangement was introduced which allows Australian and New Zealand citizens to enter each others' country freely to visit, live, and remain indefinitely without the need to apply formally for the authorization to enter the other country. Since February 2001, unless covered by special transitional provisions, New Zealand citizens are required to obtain formal permanent residence status if they wish to access certain social security benefits, obtain Australian citizenship or sponsor people for permanent residence. 
DELSA/ELSA/WD/SEM(2007)4

Table 3: Most important origin countries and regions of origin (populations in '000s) of the foreign-born in Australia, 2003

\begin{tabular}{|c|c|c|c|c|c|c|c|}
\hline \multicolumn{2}{|c|}{$\begin{array}{l}\text { Most important origin } \\
\text { countries }\end{array}$} & $\begin{array}{l}\text { share of } \\
\text { total }\end{array}$ & $\mathrm{ER}^{1}$ & Regions of origin & & $\begin{array}{c}\text { share of } \\
\text { total }\end{array}$ & $\mathrm{ER}^{1}$ \\
\hline United Kingdom & 1126.2 & $24 \%$ & $73 \%$ & Europe (incl. former USSR) & 2328.1 & $50 \%$ & $67 \%$ \\
\hline New Zealand & 428.0 & $9 \%$ & $80 \%$ & Asia & 1162.3 & $25 \%$ & $59 \%$ \\
\hline Italy & 231.6 & $5 \%$ & $64 \%$ & Oceania & 544.4 & $12 \%$ & $75 \%$ \\
\hline Vietnam & 174.6 & $4 \%$ & $59 \%$ & Middle East and North Africa & 259.0 & $6 \%$ & $48 \%$ \\
\hline China & 173.1 & $4 \%$ & $54 \%$ & Americas & 182.2 & $4 \%$ & $69 \%$ \\
\hline Greece & 130.0 & $3 \%$ & $47 \%$ & Africa (excl. North Africa) & 179.4 & $4 \%$ & $72 \%$ \\
\hline Philippines & 120.0 & $3 \%$ & $66 \%$ & Total & 4655.3 & $100 \%$ & $65 \%$ \\
\hline India & 118.3 & $3 \%$ & $76 \%$ & & & & \\
\hline Germany & 116.6 & $3 \%$ & $65 \%$ & & & & \\
\hline South Africa & 101.6 & $2 \%$ & $74 \%$ & & & & \\
\hline \multicolumn{8}{|l|}{ Pro memoria: } \\
\hline Native-born ${ }^{2}$ & 13629.5 & & $73 \%$ & & & & \\
\hline
\end{tabular}

Note: $\quad$ 1. ER: employment/population ratio of the foreign-born aged 15-64 from these origin countries/regions. 2. Census 2001.

Source: $\quad$ OECD (2005a) for the origin countries and regions. Data on employment rates by region are from the Australian Bureau of Statistics. Data on employment by origin countries are from the Survey of Education and Work 2004.

\section{Key actors}

45. Unlike many other OECD countries, where the responsibilities for entry and integration tend to be split among a broad range of government departments, DIMA in Australia is inter alia responsible for all issues relating to entry, stay, settlement services (with the exception of the education of migrant children), citizenship and multicultural affairs. It is thus the key actor with respect to migrant integration. In the 2005-2006 budget of DIMA, about A $\$ 300$ million are being spent on integration. ${ }^{21}$ About half of that sum - A \$ 155 million - is budgeted for the Adult Migrant English Program (see below), and more than A $\$ 50$ million are scheduled for humanitarian settlement services. ${ }^{22}$

46. However, the provision of many services such as income support, education and health services, is the primary responsibility of other government departments and/or other levels of government. Accordingly, there is a range of other governmental and non-governmental actors who are involved in immigrants' labour market integration, both on the national and sub-national levels. On the national level, the Department of Education, Science and Training (DEST) funds the Language, Literacy and Numeracy Programme (LLNP), which aims at improving the speaking, reading, writing and numeracy skills of eligible migrants (see below). About 50 million A $\$$ are currently being budgeted for this programme (see below). In addition, the Department is in charge of the National Office of Overseas Skills Recognition, which administers the arrangements for the recognition of their academic and professional qualifications. Australia has a comprehensive range of qualifications assessing authorities, depending on the occupation of the person in question. For example, a person applying to migrate on the basis of computing

21. Estimate based on DIMIA (2005), calculated as follows: resources for outcome 2 ("a society which values Australian citizenship, appreciates cultural diversity and enables migrants to participate equitably”), excluding money spent on citizenship decisions. $1 \mathrm{~A} \$$ is about 0.60 Euro or 0.76 US-\$.

22. Not included in these figures are the social benefits to which humanitarian immigrants have access. 
qualifications must apply to the Australian Computer Society for assessment of his/her qualifications. DEST oversights the appointment and performance of relevant assessing authorities. ${ }^{23}$

47. The Department of Employment and Workplace Relations (DEWR) is in charge of labour market policy in general. It is responsible for the employment services, which are contracted to private and notfor-profit organisations by means of the so-called Job Network (see below). In addition, it is also involved in immigration planning by providing information on current and future skills shortages. It is also in charge of the assessment of immigrants' skills with respect to occupations in the trades (see below on the assessment of foreign qualifications).

48. Like the general labour market services, integration services are generally contracted on the basis of competitive tenders. They may then be provided by private or not-for-profit organisations or by government organisations. About half of the providers are technical colleges (Technical And Further Education (TAFE) institutes), which are generally government organisations. There is also an important role of local community groups, particularly with respect to the integration of humanitarian migrants. Migrant Resource Centres, which play an important part in humanitarian settlement, are community based organisations.

49. The State and Territory governments play an important role in several key areas linked to migrant's labour market integration, particularly through their responsibilities in the areas of education and health. In addition, States and territories can sponsor migrants through a number of schemes. For example, all States and territories can sponsor migrants who are willing to settle in regional or low population growth areas (generally rural areas in the larger States). Fewer points under the points system are required in such cases. However, the above-mentioned core threshold requirements for skilled immigration still apply. Some States also provide funding to additional integration services in cases where the Federal integration aid is deemed to be insufficient. For example, Victoria funds training aimed at a better utilization of skilled migrants' skills during the first two years of settlement when access to federal support is not available.

\section{Main services provided to migrants}

\section{Services for humanitarian settlement}

50. As noted above, since 1997, immigrants in the skilled and family categories do not have access to income support, social security benefits, and most related labour market services for the first two years after arrival. ${ }^{24}$ The only exceptions to the two-year waiting period are migrants under the humanitarian programme. This group is entitled to full social security access upon arrival. Given the low employment outcomes of humanitarian migrants (see below), this is likely to account for the bulk of expenses attributable to this group. That said, programmes that improve the employability of humanitarian migrants, though costly, may pay-off in the long run.

51. There is a relatively broad range of services available for humanitarian resettlers within the first five years after arrival (Box 1). Within the group of "humanitarian migrants", the Special Humanitarian Programme migrants generally receive somewhat less support as several initial services are generally provided by the person or institution (e.g. a permanent resident or a refugee organisation) that has sponsored the migrant. Notably, the proposer has to pay for the migrant's travel to Australia, to provide

23. DEST also provides grants to State governments for the delivery of English-language training for immigrant students in primary and secondary school.

24. Nevertheless, there are a number of exceptions from the general exclusion for social benefits. In particular, immigrants may be entitled to family payments. 
immediate accommodation and to familiarise the migrant with the services available to migrants in Australia such as education and employment services. Recent changes to the Integrated Humanitarian Settlement Strategy (IHSS) aimed at improving settlement support for Special Humanitarian Programme migrants. Under the new model, which was introduced on 1 October 2005, the needs of the SHP entrants and their proposer are assessed by IHSS service providers, and assistance is provided on the basis of this assessment. Where it is assessed as necessary, SHP entrants can be provided with the full suite of IHSS services, including referral to employment services.

\section{Box 1: Australia's integration programme for humanitarian migrants}

Australia has a relatively elaborate system to ensure integration of a group whose labour market outcomes tend to be not as good as for other immigrants - humanitarian resettlers. These are individuals who have often suffered from torture and trauma and who in many cases did not have some of the most basic needs (such as access to clean water) satisfied. In addition, their educational attainment is generally relatively low. With this situation in mind, Australia provides pre-embarkation orientation for humanitarian migrants since 2003. This three-day orientation includes basic information on Australia's legal and political system, healthcare, public transport, its labour market, the education system and on the services to which resettlers have access. Australia also arranges and pays for transportation to Australia. Upon arrival, they receive intensive initial support under a scheme known as the Integrated Humanitarian Settlement Strategy (IHSS). Under this strategy, based on an initial needs assessment carried out by case workers, an initial integration plan is established for the migrant. Depending upon the individual's assessed needs, a variety of services are provided to newly-arrived entrants under the humanitarian resettlement programme. These include arranged accommodation and household formation support (including clothing), but also practical information such as when to go to a doctor. Referral to short-term torture and trauma counselling services is also provided for migrants who require these services.

Migrants also receive information about other services and mainstream agencies, including labour market institutions. The focus of the initial phase is on equipping entrants with the necessary background knowledge to enable them to independently access mainstream services. This is often assisted by local volunteer groups. The period of intensive support generally lasts about six months, but may be extended in particular cases. For humanitarian migrants sponsored by Australian residents or organisations, the services outlined above are generally supplied by the proposer. Under the new model of IHSS, which commenced on 1 October 2005, the needs of SHP entrants and their proposer are assessed by IHSS service providers. Based on this needs assessment, assistance is provided. Where it is assessed as necessary, SHP entrants can be provided with the full range of IHSS services, including referral to employment services.

Each of the basic service categories in the settlement process is competitively tendered and contracted. Payments are based on per-capita lump sums, which vary from contract to contract. Many of these publicly funded providers are community-based, although semi-private organisations also play an important role. Following an extensive review of the services (DIMIA 2003b), IHSS funds have increased from A\$ 32 million in 2003/2004 to A\$ 52 million in the 2005/2006 budget.

After the initial settlement support, humanitarian entrants are referred to the regular settlement services. These services include a continuation of information, referral and casework, for up to five years after arrival, to assist clients to become self-sufficient and to participate in Australian society. These services are targeted to humanitarian entrants, family stream migrants with low English proficiency, and dependants of skilled migrants in rural and regional areas who have low English proficiency. They thus ensure an on-going accompaniment. This is most apparent in the English language services, which are provided free to humanitarian migrants. Before they enter the formal Adult English Migrant Program, humanitarian migrants with limited or no prior exposure to formal schooling receive a Special Preparatory Program which offers them tuition in a tailored environment to help them become familiar with the process of learning English.

52. Following a review of the settlement services (DIMIA 2003b), there are now 20 contract regions for the provision of these services. For each region, a contract is given to a service provider in a 
competitive tender process. Each successful tenderer determines his own cost per service, which - after some eventual negotiations - becomes the contract price. The provider has to meet certain outputs and performance indicators. Most outcomes are measured on the basis of a customer satisfaction rating. The output and performance indicators are not linked with labour market integration, as it is not in the responsibility of settlement service providers to ensure labour market integration of clients under the current setup. Settlement service providers merely refer clients to employment services, and it is deemed the responsibility of those employment service providers to help humanitarian entrants find employment.

\section{English-language training, translation and interpretation services}

53. Language training is the principal pillar of Australia's integration support and has been provided since the establishment of a pro-active immigration policy immediately after World War II. It is noteworthy that already shortly after their introduction, from 1952 onwards, language courses focused on English for employment. Since the Immigration Education Act of 1971, all newly arrived immigrants are entitled to up to 510 hours of free English Language tuition. The Adult Migrant English Program (AMEP) is the largest expenditure item with respect to integration services, the bulk of which is spent on language training for humanitarian migrants - almost A \$ 100 million in the 2003-2004 fiscal year. The programme is administered through DIMA, and provided by contracted service providers in about 200 locations across Australia.

54. In order to ensure functional English levels for all migrant groups which enable them to make use of their skills, the AMEP as the centrepiece of the language training is complemented by two additional programmes (see Figure 4). For humanitarian migrants over 25 who are not ready for the more formal setting of the AMEP, e.g. because of lack of literacy or difficult pre-migration experiences such as torture and trauma, there is a Special Preparatory training available for up to 100 hours (up to 400 hours for young migrants if they have limited schooling). The AMEP is also accessible by means of distance learning and with the help of home tutors. For unemployed migrants who have already participated in the AMEP, additional language training may be available. Such migrants are referred to contract providers by the Australian government's welfare agency - Centrelink - if lack of English proficiency is deemed to be an employment barrier. These migrants are subsequently assessed by a contracted provider if participation in further training - the so-called Language, Literacy and Numeracy Programme (LLNP) - can be expected to improve their English language, literacy and numeracy skills. Depending on this assessment, migrants are referred to one of three different training streams. Courses in the advanced stream can cover vocationally specific English through vocational colleges and private providers (e.g. language courses with special focus on accounting and finance, computing skills or nursing). Like the AMEP, the LLNP is generally also accessible by distance education. 
Figure 4: Overview of the English-language training available to migrants

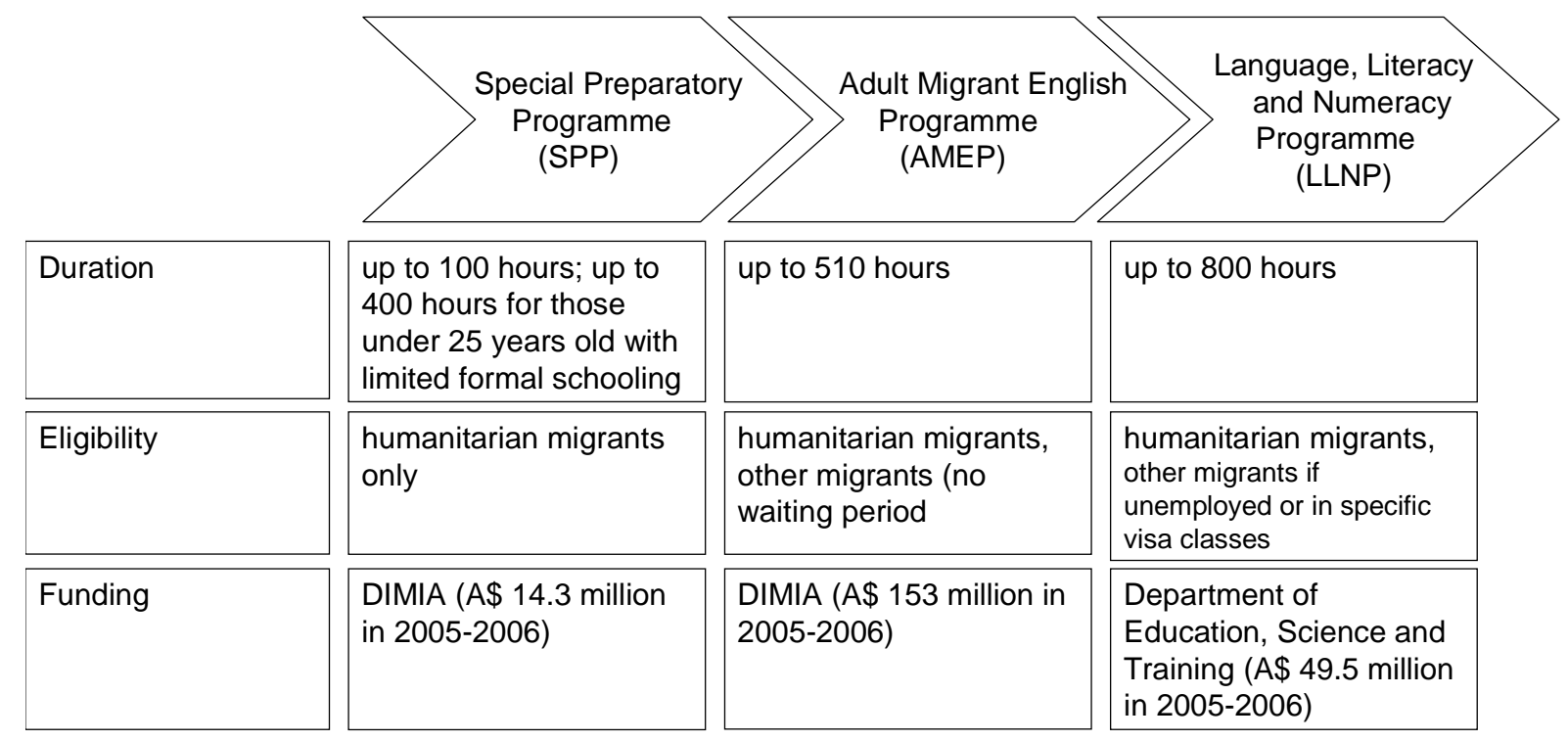

55. Considering this multi-tiered structure, English-language training is a major investment, and migrants with insufficient English skills may be eligible for a total of up to 1310 hours of such training (young humanitarian migrants even up to 1710 hours). This training is provided free of charge, but there is an additional upfront charge on the skilled visa categories for (secondary) applicants with limited English knowledge. $^{25}$

56. In addition to this relatively extensive language training, translation and interpretation services are also available. The system of translation and interpretation services is sophisticated, with assistance being provided in more than 100 languages, both on-site and via the telephone (Box 2).

57. Separate from the programmes outlined above, there is also an English as a Second Language New Arrivals programme for school students in need of intensive language training. Through this programme, the Australian Government provides funds to State and Territory education authorities to assist with the cost of delivering intensive English language tuition in primary or secondary schools to newly arrived migrant students (depending on the school year, entry is only possible up to six or 18 months after arrival). Available funding for this programme covering the period from 2005 to 2008 is estimated to be $\mathrm{A} \$ 287$ million.

25. For example, if the spouse of a migrant in the (points-tested) skills independent category has less than functional English, the application fee for the corresponding visa increases from A\$ 1935 to A\$ 4625 . This additional visa charge was originally known as the English Education Charge, which was introduced in 1993. 


\section{Box 2: The Translating and Interpreting Services}

Australia provides elaborate Translating and Interpreting Services (TIS) as a complement to the extensive language training for which most immigrants with a non-English-speaking-background are eligible. The nationwide TIS are available to any person or organization in Australia requiring interpretation aid. It has a long tradition, with fee-free translating and interpreting services being provided since 1958 and 1973, respectively.

The services are both provided on-site and via the telephone and have been greatly facilitated by advances in information and telecommunication technology. The latter are available 24 hours a day, 7 days a week, and in more than 100 languages through a network of contractors. Currently, the ten languages in highest demand are Arabic, Vietnamese, Mandarin, Serbian, Cantonese, Persian, Turkish, Spanish, Russian and Bosnian. The TIS thus mirror the growing share of immigration from non-OECD countries. For medical practitioners, there is a fee-free priority line which ensures that an interpreter for the most common foreign languages is available within three minutes. There are also special priority lines for emergency purposes. Telephone translation services are also provided free of charge for community-based non-profit organisations which provide settlement services, as well as generally for local governments and trade unions. Within the first two years after arrival or grant of permanent settlement, most immigrants also have access to free document translation services, including education and employment references. In 2003-2004, about 9000 document translations, as well as about 95000 telephone and 19000 on-site interpreting services, were provided free of charge. The annual budget cost of these fee-free services amounts to about A\$ 6.5 million.

Most other translation services are fee-based, with rates varying from about 20 to 35 A\$ per 15 minutes of telephone-based interpretation, and rates starting from about 140 A $\$$ for on-site services. In practice, however, most immigrants will not bear themselves the costs, as their relevant counterpart (e.g. a telephone company whose bill they do not understand, a bank where they want to open an account, etc.) usually agrees to pay the fee.

58. Finally, the Department of Education, Science and Training (DEST) finances a separate programme for Workplace English Language and Literacy. This programme aims at combining language and literacy training together with on-the-job vocational training. It is intended to improve skills and productivity of those already working, and enterprises are required to pay a quarter of the costs in the first year and half of the cost in the second, with the remainder being funded by DEST, at a cost of A\$ 14.5 million for the 2006-2007 financial year. The training is provided upon application by the employer. Though this programme is not limited to immigrants, they are naturally a key target group.

\section{Chapter 3: Key issues in the labour market integration of immigrants}

\section{The impact of selection policy}

59. Migrant outcomes in Australia are clearly assisted by the country's immigration policy, which favours skilled migration linked to labour market needs. Table 4 shows that skilled immigrants - i.e. those subject to selection - have substantially higher employment rates than other immigrants. This is hardly surprising, as it also applies to worker immigrants in other countries. A further observation is that the gender gaps in the employment rates are largest for immigrants in the family and humanitarian categories. In turn, employment rates of secondary applicants - of both genders - in the skilled stream (i.e. accompanying family) are relatively high. ${ }^{26}$

26. Indeed, it is surprising to note that the employment rates of male secondary applicants in the skilled stream are higher than those of the main applicants. However, relatively few migrants are in the former group, so the differences are not significant. 
Table 4: Employment-population ratios of the native- and foreign-born populations in Australia, by visa category, 15-64 years old, 2004

\begin{tabular}{|c|c|c|}
\hline & Men & Women \\
\hline Native-born & $81 \%$ & $66 \%$ \\
\hline Foreign-born & $76 \%$ & $57 \%$ \\
\hline \multicolumn{3}{|c|}{$\begin{array}{l}\text { By visa category (only immigrants to Australia after } 1984 \text { aged } \\
15 \text { and above at arrival) }\end{array}$} \\
\hline Skilled - main applicant & $86 \%$ & $79 \%$ \\
\hline Skilled - other than main applicant & $89 \%$ & $71 \%$ \\
\hline Family & $78 \%$ & $43 \%$ \\
\hline Humanitarian & $68 \%$ & $40 \%$ \\
\hline
\end{tabular}

Note: See Box 3 for the coverage of this survey. Note that the visa categories are not necessarily official administrative categories. Respondents have been classified broadly to these categories on the basis of self-reporting.

Source: Data by visa category: Labour Force Status and Other Characteristics of Migrants Survey.

60. Because of the selection policy, Australia's immigrant stock is relatively highly educated. This observation also holds in international comparison, as Table 5 shows. Whereas the immigrant population in European OECD countries tends to be less qualified than the native-born population, the opposite is the case in Australia. These figures show, furthermore, that immigrants from non-OECD countries are more highly educated than those from OECD countries.

Table 5: Share of highly-qualified persons among the adult (25-64) population, selected OECD countries, 2003-2004

\begin{tabular}{|l|c|c|}
\hline & Foreign-born & Native-born \\
\hline Australia & $\mathbf{3 8 \%}$ & $\mathbf{3 2 \%}$ \\
\hline Australia - non OECD & $42 \%$ & \\
\hline Belgium & $25 \%$ & $30 \%$ \\
\hline Canada & $51 \%$ & $42 \%$ \\
\hline Denmark & $38 \%$ & $32 \%$ \\
\hline France & $21 \%$ & $24 \%$ \\
\hline Germany & $19 \%$ & $26 \%$ \\
\hline Netherlands & $24 \%$ & $25 \%$ \\
\hline Sweden & $30 \%$ & $27 \%$ \\
\hline Switzerland & $28 \%$ & $28 \%$ \\
\hline United Kingdom & $34 \%$ & $29 \%$ \\
\hline United States & $35 \%$ & $40 \%$ \\
\hline
\end{tabular}

Note: Data refer to 2002 for the Netherlands, 2003 for Australia and Canada, and to 2004 for the United States. Highlyqualified are persons with tertiary education (Australia: diploma or above).

Source: Australia: Household, Income and Labour Dynamics Australia Survey; European countries: European Community Labour Force Survey (data provided by Eurostat); United States: Current Population Survey March Supplement; Canada: Survey of Income and Labour Dynamics.

61. Figure 5 shows that the higher employment rate of immigrants compared to that of natives in international comparison is clearly assisted by the advantageous qualification structure of the former. 
Nevertheless, even after adjusting for the favourable qualifications structure, differences in employment

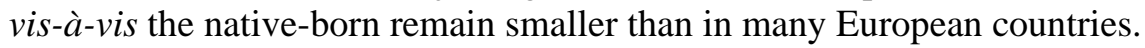

\section{Figure 5: Percentage-point differences in employment rates between foreign- and native-born and the impact of the qualification structure, 2004, 15-64}

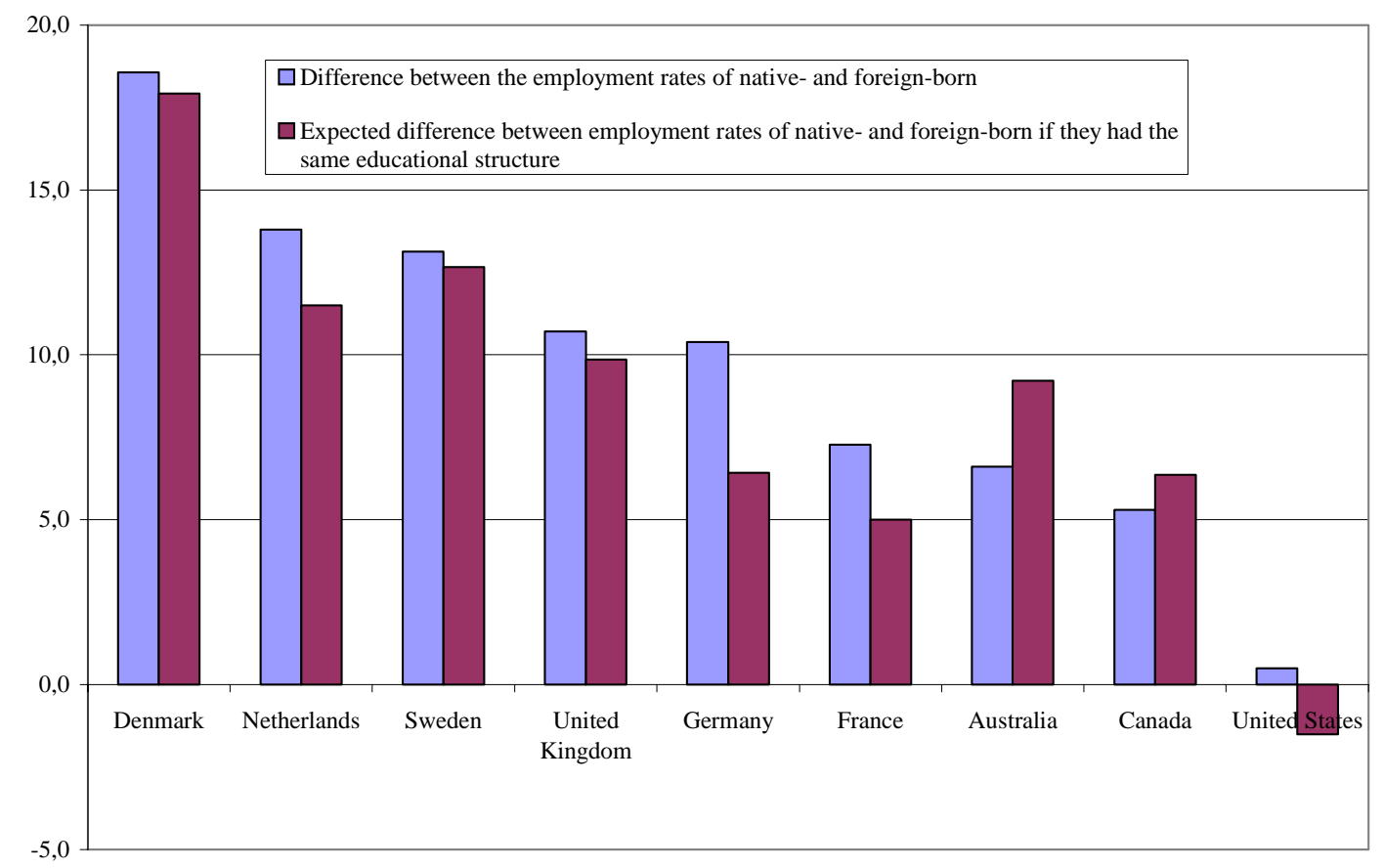

Note: Data refer to 2002 for the Netherlands, and to 2003 for Australia and Canada. The expected difference is calculated on the basis of the qualification-specific employment rates.

Source: See Table 5.

62. Selection policy also appears to have an impact on unobservable characteristics that tend to increase the probability of employment (such as e.g. a higher motivation on the part of selected immigrants). Analysis with the Longitudinal Survey of Immigrants to Australia (LSIA, see Box 3) shows that even after controlling for educational attainment and other socio-demographic characteristics, the visa category has a strong and robust influence on employment (see Annex 2a). Skilled principal applicants have higher employment probabilities than family migrants (i.e. accompanying family and family reunification). The reverse is the case for humanitarian migrants. These observations hold even after controlling for English proficiency. ${ }^{27}$ Interestingly, even if one looks only at employment progression (i.e. migrants who were not in employment in the first wave), there is a significant impact of migrant category. A similar impact of migrant category can also be observed with respect to earnings (Chiswick, Lee and Miller 2005b).

27. In this context, it should be stressed again that in contrast to skilled migrants, humanitarian entrants are not selected on the basis of the economic contribution they can make to Australia. The aim of the Humanitarian Programme is to resettle people who face persecution and discrimination and who are in need of resettlement. These individuals may also be suffering from torture, trauma and other factors which limit their participation in the Australian labour market, at least in the early years. 
DELSA/ELSA/WD/SEM(2007)4

\section{Box 3: Data and research on the labour market integration of immigrants in Australia}

In Australia as elsewhere, there is a substantial literature on the labour market integration of immigrants. The first principal data source exploited in the recent literature is the Longitudinal Survey of Immigrants to Australia (LSIA; for a discussion of the Longitudinal Survey, see Cobb-Clark 2001). This survey covers the early settlement period for two migrant cohorts, the first arriving between September 1993 and August 1995, and the second arriving between September 1999 and August 2000. It does not include individuals who applied for and received permanent residence in Australia, long-term temporary residents, New Zealanders, or holders of special eligibility visas. The first cohort was surveyed about 6, 18, and 42 months after arrival, the second 6 and 18 months after arrival. This dataset has very detailed information on visa category, migration reasons and the initial labour market experience in Australia. Problematic in the second cohort is the relatively short time span over which the migrants are surveyed only 18 months after arrival - whereas the information from the first cohort is now somewhat dated. A further disadvantage is the fact that the dataset only covers recent arrivals, making comparisons with earlier immigrants and the native-born difficult.

The second major source is census data, generally the $1 \%$ population sample of the Household Sample File. Australia conducts a census every five years, which gathers inter alia information on years-of-residence, selfreported English proficiency and parents’ place-of-birth - but no information on visa class at arrival.

Recently, a third major source is available to researchers, the Household, Income and Labour Dynamics Australia Survey. This is an annual longitudinal survey, which started in the year 2001, comprising 20000 individuals in the first wave. It also contains information on English proficiency, the place of birth of the parents, and the country in which the highest qualification was obtained. Since wave 4 (released early 2006), it also includes information on immigrants' visa category.

Another principal source is the Labour Force Survey and its supplements. However, access to the microdata is very limited outside of Australia and relatively little research is based on these data. Particularly interesting in this respect is the Labour Force Status and Other Characteristics of Migrants Survey (generally referred to as the "Survey of Migrant Characteristics"), which is conducted about every three years, most recently in 2004. With the exception of the LSIA, this is currently the only available survey containing (self-reported) information on the broad visa categories, so principal applicants can be distinguished from secondary applicants, and the visa stream can be identified. However, it does not cover all immigrant cohorts and there are some indications that the information given with respect to the broad visa categories is not always accurate. Furthermore, the 2004 survey, for example, only surveyed people who arrived after 1984 and who were aged 15 and above at entry, so it is not representative of the entire immigrant population.

Programme data are very rarely used. Although some employment-linked programme information seems to exist, this is rarely made accessible to researchers outside of Australia. The lack of available data of this kind is a handicap for the analysis of the effectiveness of labour market services with respect to certain migrant groups (see below) and language training.

\section{Outcomes of recent arrivals}

63. The impact of Australia's selection policy is particularly apparent in the early settlement process. Table 6 provides an overview of the immigration outcomes by migrant category 6 and 18 months after arrival, based on the two migrant cohorts surveyed in the LSIA. ${ }^{28}$ Labour market outcomes improved for

28. Unfortunately, the LSIA does not provide the ILO classification for employment and unemployment, and two different employment variables are provided. The data presented here follow most studies (e.g. Richardson et al. 2004) by basing employment status on the reported “current main activity”. This tends to exclude minor employment. Students with part-time jobs, for example, will not necessarily report themselves as employed (part-time) but rather as students. 
the second cohort relative to the first, for a number of reasons. Firstly, in the interval between the two cohorts, unemployment fell from nine to below seven percent, and overall employment rose by 1.26 million people or 16 percent (Richardson et al. 2004). Such a favourable labour market development certainly contributed to integrate new arrivals rapidly into the labour market, and the gap in the employment rates of recent arrivals vis-à-vis the native-born population has decreased markedly over that period.

Table 6: Employment rates by migrant category (principal migrants and spouses) at arrival and thereafter, 15-64 years old at time of arrival

\begin{tabular}{|c|c|c|c|c|c|c|}
\hline & \multicolumn{4}{|c|}{ Employment rates } & \multicolumn{2}{|c|}{$\begin{array}{c}\text { Share of total migrants } \\
\text { surveyed }\end{array}$} \\
\hline & $\begin{array}{l}\text { LSIA 1-1 } \\
(\sim 1995)\end{array}$ & $\begin{array}{l}\text { LSIA 1-2 } \\
(\sim 1996)\end{array}$ & $\begin{array}{l}\text { LSIA 2-1 } \\
(\sim 2000)\end{array}$ & $\begin{array}{l}\text { LSIA 2-2 } \\
(\sim 2001)\end{array}$ & LSIA 1-1 & LSIA 2-1 \\
\hline $\begin{array}{l}\text { Principal applicant: } \\
\text {-Spouse \& prospective } \\
\text { marriage }\end{array}$ & $36 \%$ & $47 \%$ & $44 \%$ & $55 \%$ & $38 \%$ & $37 \%$ \\
\hline $\begin{array}{l}\text {-Parent \& other preferential } \\
\text { relative }\end{array}$ & $15 \%$ & $31 \%$ & $39 \%$ & $46 \%$ & $6 \%$ & $3 \%$ \\
\hline $\begin{array}{l}\text {-Skilled - points tested - } \\
\text { sponsored }\end{array}$ & $51 \%$ & $67 \%$ & $71 \%$ & $82 \%$ & $6 \%$ & $8 \%$ \\
\hline $\begin{array}{l}\text {-Skilled - points tested - } \\
\text { independent }\end{array}$ & $65 \%$ & $80 \%$ & $79 \%$ & $84 \%$ & $14 \%$ & $20 \%$ \\
\hline $\begin{array}{l}\text {-Skilled Labour/Employer } \\
\text { Nomination }\end{array}$ & $65 \%$ & $80 \%$ & $99 \%$ & $99 \%$ & $2 \%$ & $1 \%$ \\
\hline -Refugee & $6 \%$ & $22 \%$ & $4 \%$ & $22 \%$ & $3 \%$ & $2 \%$ \\
\hline $\begin{array}{l}\text {-Special Humanitarian } \\
\text { Program }\end{array}$ & $7 \%$ & $27 \%$ & $3 \%$ & $12 \%$ & $3 \%$ & $3 \%$ \\
\hline -Special Assistance Category & $8 \%$ & $31 \%$ & $8 \%$ & $17 \%$ & $5 \%$ & $<1 \%$ \\
\hline $\begin{array}{l}\text { Spouse migrating with the } \\
\text { principal applicant in his/her } \\
\text { visa category }\end{array}$ & $18 \%$ & $30 \%$ & $38 \%$ & $46 \%$ & $22 \%$ & $24 \%$ \\
\hline Total & $34 \%$ & $52 \%$ & $50 \%$ & $60 \%$ & & \\
\hline $\begin{array}{l}\text { pro memoria: employment } \\
\text { rates of the native-born }\end{array}$ & $75 \%$ & $76 \%$ & $76 \%$ & $76 \%$ & & \\
\hline $\begin{array}{l}\text { pro memoria: GDP growth } \\
\text { (annual average) }\end{array}$ & $3.9 \%$ & $4.0 \%$ & $3.3 \%$ & $2.7 \%$ & & \\
\hline
\end{tabular}

Note: LSIA 1-1, LISA 1-2, LSIA 2-1 and LSIA 2-2 refer to the first and second waves of each of the two cohorts of the Longitudinal Survey of Immigrants to Australia, respectively (see Box 3). Some smaller groups (other humanitarian migration and business migration) are not shown separately, but included in the total. Due to small sample sizes, differences in the employment rates between some of the smaller visa categories are not significant.

Source: Longitudinal Survey of Immigrants to Australia (LSIA), memorandum items: OECD Employment Database.

64. Secondly, and equally important, the period between the two cohorts was also one of substantial change in Australian immigration policy, i.e. a move towards more selection and a greater emphasis on English language in the skills stream, which is reflected in the employment figures. In particular, there was a substantial increase in the employment of the skilled migrant groups, inter alia attributable to tighter selection criteria and the two-year waiting period for social security access (see below). At the same time, the share of skilled migrants as principal applicants among total immigration has increased by about 8 percentage points, contributing to the favourable overall evolution for new arrivals.

65. The particularly large rise in the employment of parents and other relatives between the two cohorts of the LSIA is explicable by a variety of restrictions that were placed on the preferential family 
stream. These led, in effect, to a reduction of the average age of migrants in that category (Richardson et al. 2004). In contrast to the employment rate gains observed for the skills and family streams, outcomes for humanitarian migrants have tended to decline. The reasons for this are not clear, since a decline is observed even for the same countries of origin.

66. Though not directly comparable due to different classifications, visa types and countries of origin, the outcomes for recent arrivals in the skilled and family categories tend to be above those reported for Canada in its own Longitudinal Survey (see Richardson and Lester, 2004). In contrast, employment of the humanitarian group in Australia is significantly below that of humanitarian immigrants to Canada. It reached a level similar to that observed in Canada after six months only after 18 months - i.e. 21\% (Statistics Canada 2005). However, longitudinal data from the Swedish Integration Board show that humanitarian migrants who arrived in Sweden in 1997 had employment rates of 9, 17 and 32\% in 1998, 1999 and 2000, respectively. These figures are similar to those from the second wave of the LSIA. In any case, it should be stressed humanitarian migrants only account for a small part of the annual immigrant intake in Australia (currently about 10\%), with skilled migration making up the majority of the inflows.

\section{Convergence of immigrants' employment toward that of natives}

67. Figures $6 \mathrm{a}$ and $6 \mathrm{~b}$ show the gap in the employment rates between immigrants and native-born in Australia compared with selected other OECD countries by years of presence in the host country for men and women, respectively. Note that these results are not based on longitudinal data, rather they are crosssectional data based on length of stay in the respective host countries. Nonetheless, the pattern observed is generally as expected, i.e. immigrants who have been longer in the host country have better outcomes. A notable exception are female immigrants in Australia from non-English-speaking OECD countries, where long-term residents fare worse than the 6-10 years-of-residence group. This, however, is linked to the fact that many of these older cohorts are from Southern Europe, where employment of women is low. Furthermore, these cohorts are older on average, which is associated with lower employment rates.

68. Figures $6 \mathrm{a}$ and $6 \mathrm{~b}$ also illustrate that immigrants from non-OECD countries have higher initial gaps in employment than immigrants from OECD countries. However, those immigrants from third countries who have been more than ten years in Australia exhibit higher employment rates than immigrants from the non-English-speaking OECD, which indicates a more rapid convergence of employment rates for the former. Similarly, the somewhat lower overall employment rates of non-OECD immigrants vis-à-vis OECD non-English-speaking immigrants reported in Table 1 are partly attributable to the fact that they are overrepresented among recent arrivals. Despite relatively high gaps initially, their employment rate in the long term is more favourable than that of immigrants with an OECD non-English-speaking background. The very high initial gaps vis-à-vis the native-born for male immigrants from non-OECD countries are partly attributable to the fact that this group also includes all humanitarian immigrants.

69. Nevertheless, the gaps are high initially even for non-English-speaking OECD immigrants if compared to other OECD countries. This is surprising as a variety of factors - selection policy, the selffunded nature of family migration, and the favourable economic circumstances should all operate in favour of high employment even for recent arrivals. ${ }^{29}$ This indicates the limits of the selection system, as it does not assure that immigrants have a job at arrival - unless the immigrant is employer-sponsored. Accordingly, as mentioned in Chapter 1, Australia is currently trying to increase employer-sponsored immigration.

29. Indeed, the corresponding employment rates for immigrants with less than two years of residence (43\%) are lower than the ones reported in the second cohort of the LSIA only four years earlier (50\% and $60 \%$ six and 18 months after arrival, respectively). 
Figure 6a: Differences (in percentage points) between the employment-population ratios of 1564 years old native-born and immigrant men, by years of presence in the host country, 2004

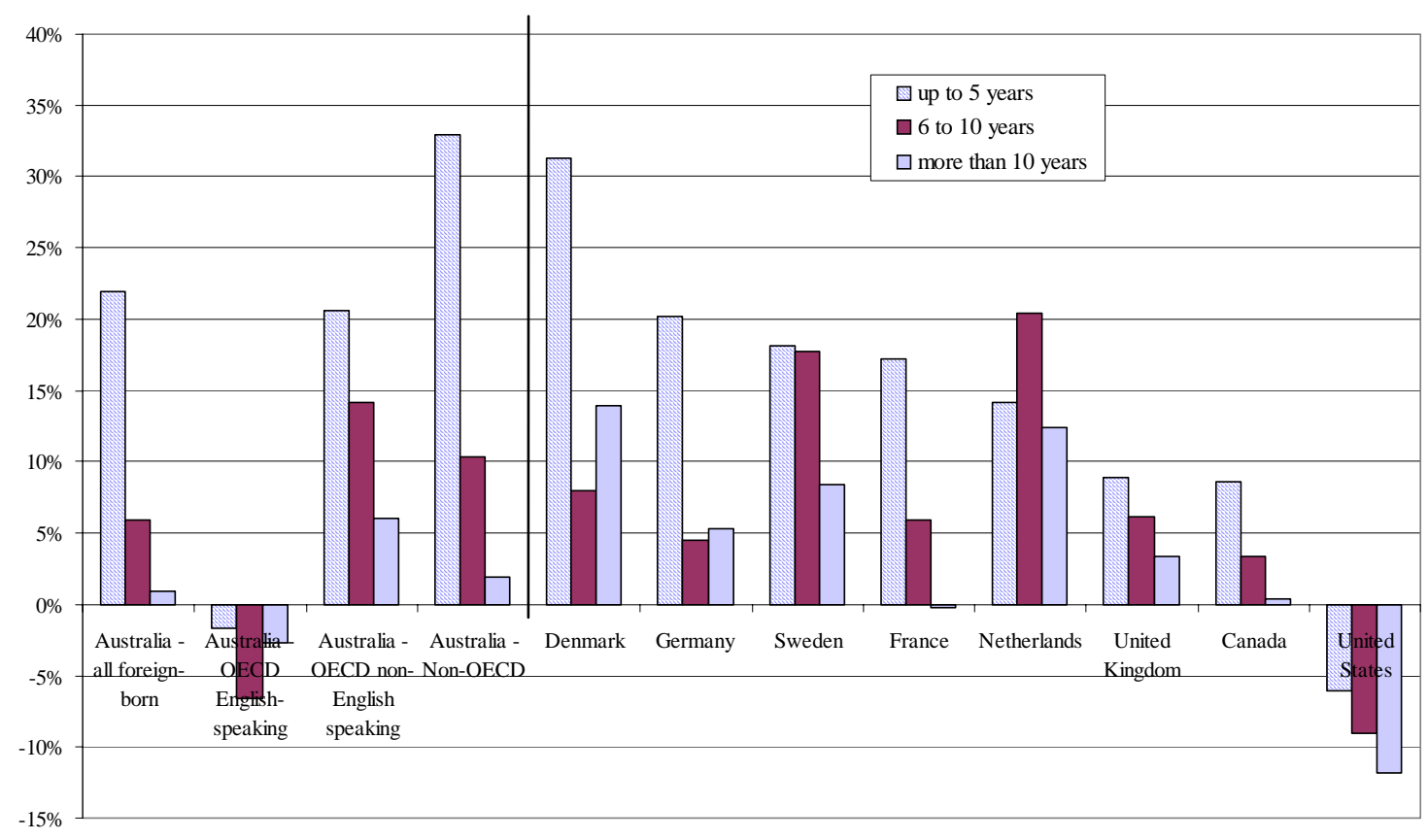

Note: Data for Canada refer to 2003.

Source: Australia: Survey of Education and Work; European countries: European Community Labour Force Survey; United States: Current Population Survey March Supplement; Canada: Survey of Income and Labour Dynamics.

Figure 6b: Differences (in percentage points) between the employment-population ratios of 15-64 years old native-born and immigrant women, by years of presence in the host country, 2004

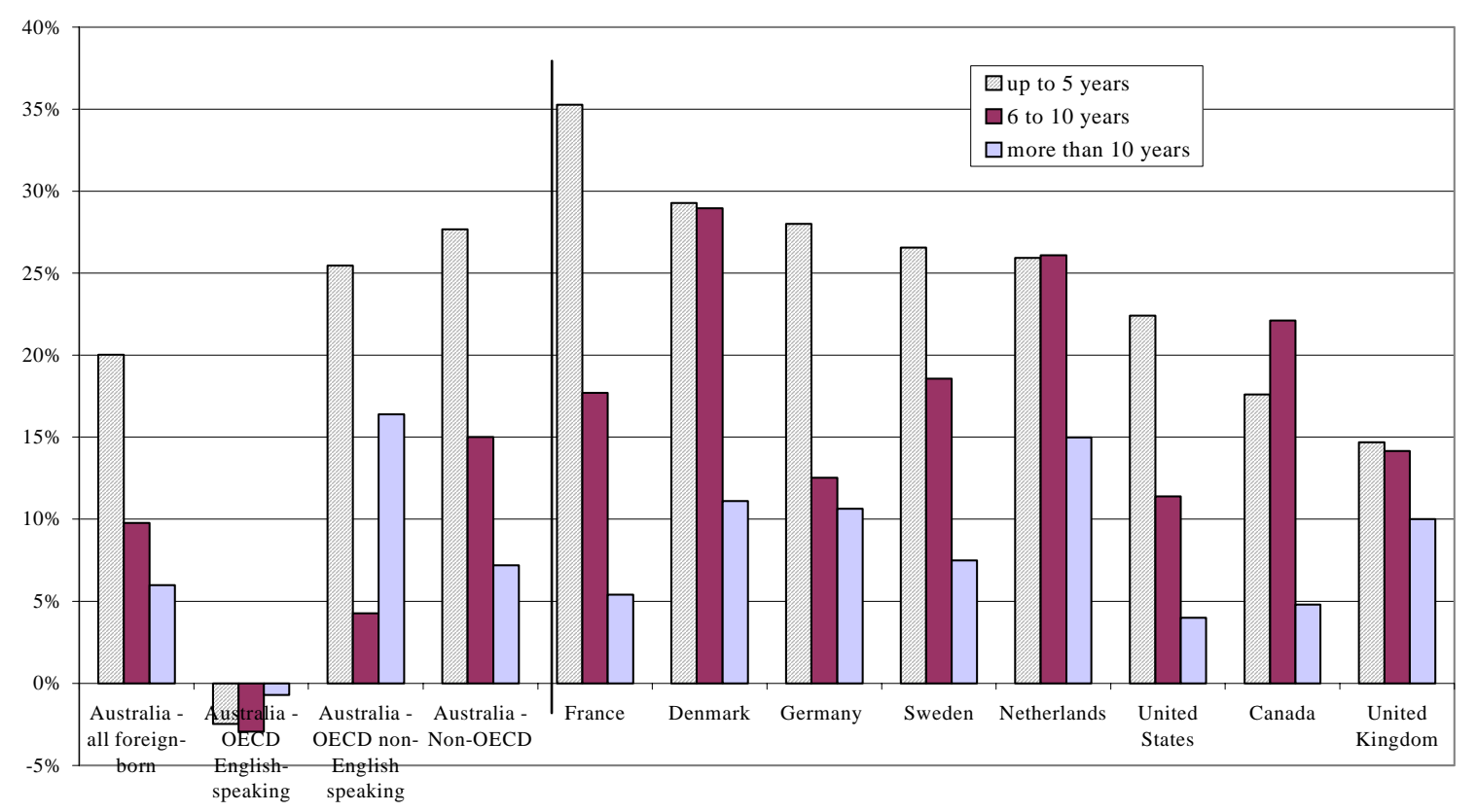

Note and Source: See Figure 6a. 
70. One noteworthy fact is the very high employment of immigrants from English-speaking OECD countries, whose rates are above those observed for the native-born even in the first years after arrival. Hugo (2004) points out that these latter figures may not be fully comparable inter alia since many recent arrivals from these countries are temporary residents coming in via the Temporary Business Scheme, particularly from the United Kingdom. This tends to inflate employment rates of these recent arrivals.

71. The observation that immigrants from non-OECD countries have initially lower employment than immigrants from OECD countries also holds with respect to unemployment with the relation reversed, i.e. higher unemployment for non-OECD immigrants than for those from OECD countries. Data from the 2004 Survey of Education and Work show that immigrants from non-OECD countries have unemployment rates of about 26\% during the first two years after arrival. Given the tight labour market in Australia and the favourable skills structure of its immigrant intake, this figure is relatively high. The situation is much more favourable for recent arrivals from OECD countries, whose unemployment stands only at $10 \%$. Unemployment of immigrants from non-OECD countries with 3-5, 6-10 and more than 10 years of residence stands at 11,9 and 5\%, respectively. In contrast, unemployment of immigrants from the OECD area remains at about $4 \%$ for all cohorts with more than two years of residence.

\section{The settlement perspective}

72. An important element in Australia's immigration policy is the settlement perspective given to migrants. All groups of non-temporary migrants get a permanent permit upon entry. In addition, as mentioned above, access to citizenship is easy and citizenship take-up is actively encouraged. These and other measures - such as the translation and interpretation services outlined above - convey a message to immigrants that they are welcome and expected to stay.

73. This settlement perspective is not only important with respect to the international competition for highly skilled migrants whom Australia seeks to attract. It can also be expected to contribute to the integration of immigrants, although this impact is difficult to quantify. Since the horizon is longer, incentives to invest in host-country-specific human capital such as knowledge about the culture and society are higher. ${ }^{30}$ To the extent such host-country-specific knowledge is valued on the labour market, higher investment into it may thus not only positively impact upon integration into the society as a whole, but also with respect to labour market outcomes of immigrants.

\section{The recognition of foreign qualifications and experience}

74. Given Australia's strong emphasis on skilled migration, the recognition of foreign qualifications is a particularly pertinent topic. Firstly, having one's skills recognised appears to have a positive impact on employment. Data from the Labour Force Status and Other Characteristics of Migrants Survey 2004 indicate substantially higher employment for individuals having their qualifications recognised - in the skilled visa group, $91 \%$ vs. $73 \%$ for those principal applicants who do not have their qualifications recognised. ${ }^{31}$

75. Equally important, it is a prerequisite for an efficient use of the strong human capital intake by skilled immigration to Australia. Awareness of recognition-related problems for migrants with overseas

30. In general, the most important component of host country specific human capital is the host country's language. English, being of widespread use, cannot, however, be referred to as being host-country specific.

31. It is often not clear what one refers to when talking about "recognition": the formal result of the recognition process or the ultimate outcome on the labour market. In the Survey, there were two possible positive answers: recognition by "employer" or by "other". The figures presented here refer to the aggregate of both categories. 
skills dates back to at least 1968, when a Government-commissioned report (Zubrzycki 1968) identified the lack of recognition of overseas qualifications as a key obstacle to migrants' integration. In response, a Committee on Overseas Professional Qualifications was founded in 1969, the predecessor of the current National Office of Overseas Skills Recognition. With the shift towards more skilled immigration in the late 1970s, the recognition of foreign qualifications gained further importance. The government-commissioned Committee of Inquiry on Recognition of Overseas Qualifications (1983, see also Hawthorne 2002) concluded in 1983 that the recognition procedure was very complex, with many skilled migrants lacking access to professional and trade placements. Despite a series of measures and improvements since then, the issue remains a topical one.

76. Australia has a sophisticated system of recognition of prior learning in whichever form this might have been achieved, and the recognition of overseas qualifications is no different in this respect. Technically, one has to distinguish between assessment and recognition. Assessment compares the skills and educational level obtained overseas with the domestic equivalents, whereas recognition is the acceptance of these skills and qualifications by the relevant authority as meeting domestic standards. Assessment is thus a precondition for recognition, and accordingly all immigrants in the general skilled migration category need to have their qualifications assessed prior to application. This process of preapplication assessment of overseas skills and qualifications serves two principle purposes. The first is to assess the general skills level of potential migrants, i.e. to judge whether their general human capital meets the standards set by the relevant bodies (e.g. the Australian Computer Society for IT professionals). ${ }^{32}$ This assessment of educational qualifications is generally done by professional bodies following guidelines established by the National Office of Overseas Skills Recognition, which has inter alia edited education profiles for more than 100 countries. These profiles contain information about the structure and qualifications of all sectors of the respective country's education system and the comparison criteria used for assessment purposes. Australia is also engaged in a variety of international agreements and conventions aimed at the mutual recognition of professional qualifications such as the Asia-Pacific Regional Recognition Convention.

77. Only skilled migrants need their qualifications to be assessed prior to application. For other migrants, onshore assessment of overseas qualifications is provided by the States and Territories, based on guidelines developed by the National Office of Overseas Skills Recognition. Victoria, for example, provides these services for free and links them with additional vocational and career advice, including the options for upgrading one's overseas qualifications.

78. Clearly, having one's qualifications certified does not necessarily imply a job in this particular occupation, since the assessment does not imply a work offer. This situation is, in principle, no different for the native-born, who also do not necessarily work in the profession for which they are qualified. Yet, the situation for the foreign-born differs in two important ways. Firstly, selection of the migrants via the points system favours occupations in which a shortage is perceived. ${ }^{33}$ The nature of the Australian point system, by applying a higher weight for occupations in high demand, should contribute to limiting the phenomenon of occupational downgrading. ${ }^{34}$ Presumably, tight labour market subsegments in such

32. However, assessment of educational qualifications is not done separately from the assessment process carried out by the assessing authorities regarding particular skills.

33. In this context, it has to be noted that few occupations are on the occupational shortage list, which should not be confounded with the much broader skilled occupation list. Having an occupation on the latter is a basic requirement for entry under the skilled migrant programme.

34. Occupational downgrading, or “overqualification”, refers to people holding a job that requires lesser qualifications than would theoretically be available them given their level of education. A person with a tertiary education (Australia: diploma and above) who is working in an occupation that is not at least 
professions would tend to limit the risk of being downgraded. However, as the IT boom period around the turn of the millennium has shown, this demand may be very temporary.

79. Secondly, it may be less apparent for immigrants than for the native-born whether the skills level meets the particular occupational skills demanded. Therefore, the second task of pre-application assessment is to compare an applicant's specific skills with those demanded in a particular profession in Australia. This is done by the relevant assessing authority for each respective occupation. In contrast to the recognition of education levels for skilled migrants, full occupational skills recognition is not always assured prior to entry. Once resident in Australia, immigrants wishing to practice certain regulated professions (e.g. some trades, health-related occupations and law) must additionally be licensed or at least registered by the relevant authority in the State in which they settle before they can practise that particular occupation. ${ }^{35}$ A positive outcome of the skills assessment - i.e. the acceptance as a skilled migrant - does not guarantee registration in the profession under consideration. Furthermore, employment in a range of self-regulating professions requires eligibility for membership in the respective professional bodies. In summary, the procedures and bodies responsible for recognition often differ across occupations, which tends to make the process fairly complex.

80. Immigrants do not always appear to be aware of these additional hurdles after immigration, despite the fact that the assessing authorities are in principle obliged to inform them about potential further requirements. One of the reasons may be a perception that these additional requirements will be easily met, particularly if they have professional qualifications in an occupation from the shortage list. There is anecdotal evidence that this is leading to some frustration among recent arrivals. ${ }^{36}$ An inquiry is currently under way with respect to overseas skills recognition, upgrading and licensing in Australia, and a first report is expected by mid-2006. Among the issues under investigation is a better management of immigrant expectations.

81. There are a variety of measures in place which target the problem of recognition of foreign qualification, both on an ex-ante and on a post-migration basis. With respect to the former, the points system now favours skilled migrants with Australian qualifications. In 2003-2004, about 55\% of the principal applicants who immigrated in the skilled independent visa group had Australian qualifications. The evolution towards Australian qualifications is also mirrored in the growing onshore component of Australia's skilled immigration programme. In 2004-2005, 37\% of the skilled migration intake was onshore, the majority being former students. The onshore share has more than doubled in the past five years. The recent efforts to increase employer-sponsored skilled migration should also be viewed in the context of skills recognition, since an employment offer in a skilled job implies recognition of the immigrant's skills. Nevertheless, an employer-sponsored migrant may still need to have his skills assessed by the relevant assessing body.

82. Econometric analysis with the 2003 Household, Income and Labour Dynamics Australia Survey indicates that immigrants with Australian qualifications tend to have a higher employment probability than those with similar characteristics (age, gender, marital status, education level, years of residence, region of

classified as associate professional level is considered to be downgraded and overqualified (see OECD 2005c for details).

35. Under the Australian constitution, professions or occupations are regulated at the State level, not at the federal level.

36. However, the overall satisfaction with life in Australia is relatively high, even for skilled migrants. More than $90 \%$ of all skilled immigrants under the points test surveyed in the second wave of the second cohort of the LSIA around 2001 were satisfied or very satisfied, a figure that is only slightly below the overall satisfaction for migrants. The results are very similar with respect to the question of whether or not the decision to migrate to Australia was right. 
origin, mother tongue) (see Annex 2b). However, the impact appears to be relatively small compared to that of having English as a mother tongue, or a high education level, and the results are on the margin of significance. ${ }^{37}$ This is also confirmed in analysis with the LSIA, where Australian qualifications generally did not have a significant impact - which may in part be attributable to the fact that in both cohorts few migrants had Australian qualifications (Annex 2a - Model 3). However, in the analysis with the Household, Income and Labour Dynamics Australia Survey, qualifications from English-speaking countries tended to have a slightly stronger impact on the employment probability than Australian qualifications (Annex 2b). This suggests that it may not be Australian qualifications per se which matter, but rather qualifications from an education system that is viewed as similar to the Australian. However, Australian qualifications seem to have a substantial impact on wages. Chiswick, Lee and Miller (2005b), using data from the LSIA, calculate that immigrants with Australian qualifications have about $12 \%$ higher earnings than immigrants with otherwise similar characteristics.

83. The trades are a main area where State level requirements have been an issue. The Council of Australian Government - the meeting of the heads of the various levels of government - thus agreed on 10 February 2006 that new arrangements will be implemented to make it easier for migrants with trade skills to work as soon as they reach Australia by establishing full assessment processes overseas initially in the five main source countries for Australia's skilled migrants for six priority trades in short supply by 1 July 2007 and later (i.e. by December 2008) for other skilled trades.

84. Furthermore, DIMA has just released a National Skills Recognition Information website, in collaboration with the respective ministries for education and labour (DEST and DEWR) and the State and Territory governments. The aim of this portal is to provide improved access to information about Australia's skills assessment and recognition processes for both potential migrants and for those already resident in Australia who do not have their skills already assessed (i.e. mainly those entering Australia under the Family Stream or the Humanitarian Program). This portal also aims at helping employers in regional areas to find out about skills recognition, registration and licensing requirements for skilled migrants they wish to sponsor. While this portal will not reduce the complexity of the current system, it should improve transparency.

85. On an ex-post basis, i.e. for resident migrants with overseas qualifications, there is a loan scheme for participation in bridging courses to meet entry requirements in their respective profession. Furthermore, under certain conditions there is a subsidy available for those immigrants who need to pass (additional) assessments and examinations to obtain recognition of their overseas qualifications. Again, these measures should mainly affect migrants from the family stream and the humanitarian programme.

86. Even in the absence of formal barriers (i.e. when occupational qualifications are fully recognized), skilled migrants may still face the particular problem of getting a job which matches their skills because of a lack of Australian job experience. The issue is particularly pertinent now due to the large increases in the numbers of skilled migrants. Technically, these migrants have the skills needed for labour market success, but they often lack Australian workplace experience which hampers their access to more skilled professions.

87. Nevertheless, having one's qualifications recognised limits exposure to overqualification. Data from the Labour Force Status and Other Characteristics of Migrants Survey show that among those highly qualified immigrants surveyed who had their qualifications recognised, about two thirds were working in

37. Data from the Labour Force Status and Other Characteristics of Migrants Survey seem to confirm this relatively low impact, but the surveyed number of persons with Australian qualifications is too small to produce reliable estimates. 
jobs which matched their qualifications. In contrast, only about one fourth of those highly qualified migrants who did not have their qualifications recognised were working in highly skilled jobs. ${ }^{38}$

88. As Table 7 shows, overqualification - measured by the per cent of employed highly qualified individuals working in jobs that can be classified as low- and medium-skilled ${ }^{39}$ - tends to affect immigrants more than the native-born. This is a common phenomenon in OECD countries (see OECD 2005c), and the incidence of overqualification is not higher in Australia than elsewhere. ${ }^{40}$ It appears to be particularly a problem for immigrants from non-OECD countries, which is of some concern since these account for the majority of recent arrivals. Apparently, despite the formal recognition processes in place, employers do not value qualifications from these countries as equivalent to Australian ones. ${ }^{41}$

\section{Table 7: Per cent of employed highly qualified individuals in low- and medium-skilled jobs in various OECD countries, 15-64, 2003-2004}

\begin{tabular}{|l|c|c|c|}
\hline & Foreign-born & Native-born & Ratio \\
\hline Australia & $\mathbf{3 1 . 9}$ & $\mathbf{2 3 . 1}$ & $\mathbf{1 . 4}$ \\
\hline Australia-OECD English-speaking & 20.4 & & 0.9 \\
\hline Australia-OECD Non-English-speaking & 30.5 & & 1.3 \\
\hline Australia-Non OECD & 39.1 & & 1.7 \\
\hline Canada & 33.3 & 18.5 & 1.8 \\
\hline Denmark & 22.4 & 13.3 & 1.7 \\
\hline France & 21.2 & 18.5 & 1.1 \\
\hline Germany & 33.5 & 22.2 & 1.5 \\
\hline Sweden & 25.2 & 10.4 & 2.4 \\
\hline United Kingdom & 23.2 & 22.2 & 1.0 \\
\hline United States & 28.0 & 23.3 & 1.2 \\
\hline
\end{tabular}

Source: Australia: Survey of Education and Work; European Countries: European Community Labour Force Survey; United States: Current Population Survey March Supplement; Canada: Survey of Labour and Income Dynamics.

Note: Data for Australia refer to 2004, for Canada to 2003, and for the United States to 2002.

89. It is interesting to note that the above-mentioned differences in the incidence of overqualification between natives and the main immigrant groups do not seem to be perceived as large by the migrants concerned. Data from the Household, Income and Labour Dynamics Australia Survey 2003 show that the share of migrants who state that they do not use many of their skills and abilities in their current job is not significantly higher than that of natives. Furthermore, there is little difference between OECD and nonOECD migrants in this respect.

38. However, one should be careful in interpreting these figures as one possible response in the survey was "qualifications recognised by the employer". These figures therefore do not provide evidence on the effectiveness of the assessment and recognition process.

39. For an in-depth discussion of overqualification in OECD countries and of the respective classifications, see OECD (2005c).

40. However, it is noteworthy that the two countries with strong selection policies - Australia and Canada figure among the ones with the highest rates of overqualification.

41. However, many family migrants and spouses of skilled migrants who are highly-qualified may not have undergone the recognition process. 
90. The incidence of overqualification seems to be particularly pronounced in the first years after arrival, and especially for immigrants from non-OECD countries (Table 8). 60\% of employed recent highly skilled arrivals (i.e. diploma and above with 1-2 years of residence) from non-OECD countries are not working in jobs matching their qualifications, and $23 \%$ of these even work in elementary occupations.

Table 8: Per cent of employed highly qualified immigrants in low- and medium-skilled jobs in Australia, by years of residence and country of origin groups, 15-64, 2004

\begin{tabular}{l|cccc}
\hline Number of years of residence $\rightarrow$ & $1-2$ & $3-5$ & $6-10$ & $11+$ \\
\hline All foreign-born & $47 \%$ & $42 \%$ & $40 \%$ & $27 \%$ \\
OECD English-speaking & $\ldots$ & $33 \%$ & $21 \%$ & $18 \%$ \\
OECD non-English-speaking & $\ldots$ & $35 \%$ & $\ldots$ & $26 \%$ \\
Non-OECD & $60 \%$ & $47 \%$ & $46 \%$ & $34 \%$ \\
\hline
\end{tabular}

Source: Survey of Education and Work.

91. The relatively high incidence of overqualification for migrants from non-English-speaking countries - in particular for non-OECD migrants - results in lower returns to qualifications for these individuals. ${ }^{42}$ Kler (2005) estimates the return to qualifications of male migrants with a non-English background to be about 7\% lower than those of comparable native-born. This figure seems to be a bit more favourable than the results obtained for the return to foreign qualifications in Canada, where immigrants are estimated to have about 12\% lower returns (Ferrer, Green and Riddell 2006; see also Aydemir and Skuterud 2005). In this context, it should be noted that shifts in the composition of immigrants in Canada towards persons of non-European origin were accompanied by returns to foreign experience falling from positive values in the 1980s to essentially zero in the 1990s (Green and Worswick 2002; Ferrer, Green and Riddell 2006). Lower returns to qualifications for immigrants, particularly for those from non-OECD countries, have also been observed for immigrants to Sweden (OECD 2004).

\section{The impact of the waiting period on labour market outcomes}

92. One potential explanation for the high incidence of overqualification in Australia, particularly in the early years of settlement, is the two-year waiting period before immigrants become eligible for social benefits. This could incite immigrants to take up a job more quickly, even at the expense of substantial occupational downgrading. At a first glance, this does not appear to be the case. Richardson et al. (2004) show that a larger part of the qualified migrants had found jobs after six months that, based on the migrants' subjective evaluation, used their qualifications "most of the time". In the descriptive analysis of the Richardson, however, it remains unclear to which degree this is attributable to other changes, notably in the selection criteria (see above). Based on an econometric analysis with the two cohorts of the LSIA which controls for some of the resulting changes in observed characteristics, Junankar and Mahuteau (2005) find that immigrants who arrived after this policy change take up a job more quickly, but are less likely to end up in a job which uses their prior qualifications.

93. Nevertheless, using data prior to the policy shift, Chiswick, Lee and Miller (2005a) show that those migrants who got into employment soon after arrival tended to have a higher occupational status than those who did not, but the effect was not very significant. Moreover, as Table 6 has shown, employment of skilled migrants has increased substantially after the introduction of the waiting period. Richardson, Robertson and Ilsey (2001) therefore argue that the introduction of the waiting period might have shifted the immigrant intake towards individuals who tend to find employment more quickly, but the causality is not clear.

42. To some degree, overqualification can also be interpreted as a sign of discrimination (see below). 
94. Everything considered, whereas the immediate budgetary impact of the two-year waiting period appears to be straightforward, ${ }^{43}$ there may be some trade-off with respect to employment. On the one hand, the waiting period tends to raise employment of recent arrivals, which may also have a positive impact on their employment in the longer run (see OECD 2004). On the other hand, there is some evidence that it may have exacerbated the problem of overqualification. The key question in this respect is the potential long-term impact of initial downgrading on future employment and career prospects. To study this question adequately, one would need longitudinal data that cover a decade or more of settlement experience, which are currently not available.

95. Due to the waiting period which affects eligibility for most job-search support schemes, there are no programmes in place which target the problem of overqualification at the federal level. In contrast, some States have established their own programmes targeted at skilled migrants. ${ }^{44}$ In Victoria, for example, the Overseas Qualified Professionals Program (OQPP) provides recently arrived overseasqualified professionals with a work-experience placement, to enhance their opportunities for employment in their profession. The participants are either unemployed or employed in low-skilled jobs. The program consists of an initial six weeks of training to develop job-search skills, followed by a four to six-week work-experience placement in the field of choice or in a closely related occupation. The classroom component can also be completed part-time and on-line in order to allow those participants who are in gainful, low-skilled employment to continue their activity. The work placement component is generally not remunerated. ${ }^{45}$ The programme includes mentoring elements and industry-specific networking sessions with employers and professional associations to provide further orientation and networking opportunities. There is no cost to the employer, and the budget cost per participant amounts to A\$ 1600 . More than $60 \%$ of participants were in paid employment in a field that is associated with their skills and experience six months after completion. The service started in 2001, and a further evaluation of the first programme round covering 280 participants until 2004 is currently under way. About one third of all participants were professionals in Information Technology, and a further 17 percent were engineers. The programme has now been expanded to an additional 500 migrants until 2007.

96. Less structured, but with a somewhat similar focus, are mentoring programmes. Mentors are people who meet with some selected migrants on a regular basis and share their experiences and knowledge (e.g. how to conduct a job interview, how to contact potential employers) with them. Since the mentors are often matched with the migrants on the basis of a common professional background, they may also provide the migrant with access to professional networks. Mentoring in Australia is relatively low-cost for the public budget since the mentors are generally unpaid volunteers. However, they do undergo training prior to being assigned, so the programme is not cost-free.

97. These programmes receive funding inter alia from the Australian government's Living in Harmony initiative, which aims at developing local solutions against racism. Important in mentoring is the dedication of the people involved - though it appears that, wherever such schemes have been implemented, finding a critical mass of volunteers was generally not a problem. As they help to overcome information asymmetries, mentoring schemes seem to be an effective measure. Due to the personal element which is

43. The waiting period seems to have been partly motivated by research which suggested that immigrants' probability of receiving unemployment benefits at the beginning of the 1990s was higher than that of comparable native-born (Nahid and Shamsuddin 2001). Despite this, the budgetary impact of the measure has been estimated to be very modest (OECD 2003).

44. Such schemes are currently in place in Victoria and South Australia. New South Wales ran a similar programme - the Skilled Migrant Placement Program - until 2004.

45. In late 2005, Victoria also introduced a programme - the Workforce Participation Partnerships - providing paid work experience for unemployed jobseekers ineligible for the regular labour market services (see below). Refugees and recently arrived migrants are a key target group of this programme. 
key to mentoring and a general lack of data on the outcomes, it is, however, difficult to evaluate the effectiveness of such programmes.

\section{Immigrants and the Job Network services}

98. Support for people seeking employment in Australia is provided by means of the so-called Job Network, a network of private for profit and not-for-profit contractors providing job-placement support and related services (see OECD 2001 for an in-depth discussion). The most basic service is job-search support (job placement), which consists of gathering vacancies from employers and matching the skills and experience of job seekers to job vacancies, as well as advice on job-search techniques and career options. This is the only service available to migrants subject to the two-year waiting period for social benefits. In addition, the Job Network administers Intensive Support - aimed at improving the chances of the longterm unemployed or otherwise disadvantaged (which may inter alia include Job Search Training).

99. A key element of the competitive design of the Job Network is client choice, i.e. each job seeker is free to choose a service provider that best meets his needs. This has led some Job Network providers to specialise in providing supports for migrants.

100. There is some information available on participation in the main services and employment outcomes three months after programme participation, which is presented in Table 9 below.

Table 9: Job Network services, immigrant participation and outcomes

\begin{tabular}{|l|c|c|c|c|}
\hline \multicolumn{1}{|c|}{ Instrument } & $\begin{array}{c}\text { Overall scale } \\
\text { (Exits in 2004) }\end{array}$ & $\begin{array}{c}\text { Migrant share } \\
\text { (Non-English- } \\
\text { speaking) }\end{array}$ & $\begin{array}{c}\text { Overall outcome } \\
\text { (\% employed) }\end{array}$ & $\begin{array}{c}\text { Migrant outcome } \\
\text { (Non-English- } \\
\text { Speaking) }\end{array}$ \\
\hline $\begin{array}{l}\text { Intensive Support - } \\
\text { overall }\end{array}$ & 292883 & $16.0 \%$ & $47 \%$ & $43 \%$ \\
\hline $\begin{array}{l}\text { Intensive Support - } \\
\text { Job-Search Training }\end{array}$ & 154993 & $14.3 \%$ & $54 \%$ & $48 \%$ \\
\hline $\begin{array}{l}\text { Intensive Support - } \\
\text { Customised Assistance }\end{array}$ & 256820 & $15.2 \%$ & $45 \%$ & $81 \%$ \\
\hline $\begin{array}{l}\text { New Enterprise } \\
\text { Incentive Scheme }\end{array}$ & 6132 & $16.7 \%$ & $84 \%$ & $35 \%$ \\
\hline Work for the Dole & 73322 & $12.3 \%$ & $32 \%$ & $32 \%$ \\
\hline
\end{tabular}

Source: Labour Market Assistance Outcomes - year ending December 2004 (DEWR 2005), Table 1.1 (notably Job Network Eligible (JNE) and Job Search Support Only (JSSO)) and Table 1.6 (Culturally and Linguistically Diverse - CALD - and note 3); and Labour Market Assistance Outcomes - year ending December 2004 (DEWR 2005), Table 1.1 and Table 1.4 (CALD), respectively.

Note: Post assistance outcomes are measured three months after the job seeker ceases assistance. The table refers to post assistance outcomes achieved by 31 December 2004 for job seekers who exited in the 12 months to 30 September 2004 . Data used provides only a proxy for migrants' participation and outcomes. Non-English-speaking excludes migrants from English-speaking countries such as the UK and New Zealand but may include second generation Australians who still speak a language other than English as their first language.

101. In addition to these policies directly aimed at placing people into jobs, there are some further labour market programmes which target this objective in a somewhat more indirect way. The Work for the Dole programme aims at involving participants in projects that are of value to the community. Employment, however, is not an immediate objective.

102. The Job Network also administers a separate programme - the New Enterprise Incentive Scheme (NEIS) - that is aimed at assisting unemployed people to establish a small business. In the first year upon establishment, participants get a range of support services such as business advice and mentoring, in 
addition to some financial support. The scheme is relatively minor in numbers, the number of places is currently fixed at 6800 per year. About 16\% of the participants are foreign-born.

103. An assessment of the NEIS (Kelly et al. 2002) indicated that the scheme is relatively effective in promoting self-employment among non-English-speaking immigrants, with survival rates (i.e. enterprises still running two years after the programme) being significantly higher than among the native-born (including immigrants from English-speaking countries) (65\% versus 55\%). This suggests that such mentoring-oriented schemes may be particularly effective in fostering immigrant self-employment.

104. Given the lack of disaggregated data for the other programmes mentioned above, a further analysis of the Job Network services is unfortunately not possible. To do this, more detailed data on the programme outcomes for certain immigrant groups, in particular for recent arrivals and by qualification level, would be needed. Ideally, such data would encompass visa category and country of origin - as recommended by the Review of Settlement Services (DIMIA 2003).

\section{Importance of English language and effectiveness of language training}

105. The widespread use of English in many parts of the world is a factor that provides Australia with a "natural" integration advantage which many other OECD countries do not have. $45 \%$ of the migrants questioned in the Household, Income and Labour Dynamics Australia 2003 survey stated that English was the first language which they used.

106. Data from the Labour Force Status and Other Characteristics of Migrants Survey 2004 show that employment of immigrants in Australia is strongly correlated with their knowledge of the English language, even after controlling for visa category. ${ }^{46}$ Within the family category, immigrants who spoke English well (self-reported) had employment rates that were twice those with limited or no English mastery (65\% versus 31\%). The situation was similar with respect to the outcomes for humanitarian migrants (68\% versus 32\%). To some degree, the relatively lower employment outcomes for immigrants from other than English-speaking countries are thus linked to the fact that they have a lower level of English mastery, although discrimination cannot be ruled out (see below).

107. Despite Australia's substantial investment with respect to language training - which is by far the most important item on the budget with respect to integration services - there has been no evaluation on how much and what kind of language training is most effective with respect to the aim of labour market integration. Indeed, there are no data publicly available on employment status after completion of language courses. ${ }^{47}$ This is surprising given the otherwise relatively elaborate statistical infrastructure.

108. In an analysis with the first cohort of the LSIA (Annex 2c), a significant impact on employment three years after arrival for those immigrants who did not have sufficient mastery of English (i.e. English spoken less than well) and who attended an English course at wave one can be observed. However, such a result was only obtained for those who were not in employment at wave one. When considering the entire group of immigrants with no English mastery, there was no significant impact. For those in employment at

46. Similarly, data from the Household, Income and Labour Dynamics Australia Survey demonstrate that highly-qualified immigrants who spoke English as their first language were more often employed than those who did not.

47. There is no information on the labour market status after completion of the AMEP. There is a postprogramme monitor with respect to the LLNP - which includes employment - but the data have not yet been made available to researchers outside of Australia. 
wave one, the corresponding coefficient of language training was even negative. ${ }^{48}$ This suggests that there may be a trade-off in the sense that formal language training (at least partly) keeps people out of the labour market for the time of the training. ${ }^{49}$ This may have a negative long-term impact since for the (limited) time horizon covered by the LSIA, a strong influence of early labour market experience on the later employment probability was observed. Likewise, evidence from Sweden (OECD 2004) suggests a diminution of the positive effect of language training after 500 hours, with early employment having in turn a very strong impact on subsequent employment. However, these results may be due to positive selfselection out of language training. Furthermore, the LSIA does not capture any long-term impact that language training may have.

\section{Discrimination}

109. Without a common measure of human capital, it is difficult to assess the incidence of discrimination. Experience in European OECD countries suggests problems of entry into the labour market which may be attributable to discrimination, but relatively good wage progression once employed (see e.g. the companion report on Germany, OECD 2005b).

110. In Australia, access to paid employment per se mainly seems to be a problem in the first years of settlement, and migrants with a non-English-speaking background are more affected by this. Junankar, Paul and Yasmeen (2004) show that the unemployment probability of Asian immigrants surveyed in the first three waves of the LSIA is significantly higher than that of the other immigrant groups, even after controlling for socio-economic characteristics - including visa-group and English proficiency. For Asian women, however, the unexplained part of the observed higher unemployment probability disappeared after the first wave.

111. Thapa (2004), using data from the 2001 Household, Income and Labour Dynamics Survey, finds a persistently higher unemployment risk for immigrants from non-English-speaking countries vis-à-vis the native-born and migrants from English-speaking countries after controlling for socio-demographic characteristics. The higher unemployment risk for the former is most pronounced during the early years of settlement. This suggests that language problems may account for a large part of the differences. However, the unemployment risk of migrants from non-English-speaking countries does not approach that of the native-born even after 25 years, although the remaining differences do not appear to be very large. Furthermore, for the limited number of immigrants from non-English-speaking countries who claim English to be their first language, there was no significant impact of English proficiency on reducing the higher unemployment probability of the group vis-à-vis immigrants from English-speaking countries. This suggests that a lower mastery of the English language does not fully explain the disadvantage of immigrants from Non-English-speaking countries.

112. Under the current tight labour market in Australia, discriminatory hiring and layoff practices seem to be less a problem than observed in the studies cited in the preceding paragraph which related to years in which unemployment was higher. Indications of this are the relatively low overall unemployment rates of non-OECD immigrants and the low incidence of long-term unemployment reported in the introduction. Furthermore, in the 2004 Survey of Job Search experience, only about 2\% of the unemployed immigrants from non-OECD countries reported difficulties in finding work that are related to their ethnic background.

48. All regressions in the Annex are weighted with normalised sample weights. Due to the small number of persons who have both limited English mastery at wave 1 and an employment, the coefficients are not significant. When using actual sample weights, the coefficients become significant.

49. In the active labour market policy evaluation literature, this is referred to as a "lock-in effect”. 
113. Voon and Miller (2005), using the 1996 Census of Population and Housing Sample File, find that, after controlling for education, experience, marital status, and gender, migrants from English-speaking countries earn about 4\% more than Australian-born workers. In contrast, depending on the assumed earnings function, migrants from non-English-speaking countries earn between 9 and 12\% less than comparable Australian-born. This is similar to the wage gap estimates obtained for Denmark (Constant and Schultz-Nielsen 2004) and Germany (OECD 2005b), but somewhat above those calculated for Sweden (le Grand and Szulkin 2002).

114. Nevertheless, the extent to which lower wage levels may be attributable to discrimination is difficult to assess. The fact that residual differences with respect to the wage level remain even after controlling for a range of observable socio-economic characteristics suggests that wage discrimination is a possibility. Lower wage returns for non-English-speaking immigrants appear be particularly pronounced in the first years after arrival. Chiswick, Lee and Miller (2005b) show that among the immigrants surveyed in the first cohort of the LSIA, those coming from English-speaking OECD countries have about 30\% higher wages after three to four years in Australia than other immigrants, even after controlling for qualifications, visa category, and English proficiency. These estimates for the wage gaps of recent arrivals from nonEnglish-speaking countries are substantially higher than those reported above which refer to all immigrants from these countries. This indicates a faster earnings growth among immigrants from non-Englishspeaking countries, in line with the findings of Thapa (2004) on unemployment.

115. One possible explanation for the evidence concerning overqualification among immigrants cited above could in fact be discrimination, but it is difficult to claim this with any degree of confidence. Given Australia's elaborate system of recognition of overseas qualifications, however, one would have expected a lower incidence of overqualification, because of a greater formal transferability of qualifications earned overseas.

116. In sum, there are some indications of lower wages for immigrants and of more frequent occupational downgrading, but problems of access to the labour market appear to be more limited than elsewhere.

\section{The outcomes of humanitarian migrants}

117. It is difficult to compare the outcomes of humanitarian migrants internationally, for several reasons. Firstly, few countries have separate data on the employment of humanitarian migrants. Secondly, country-of-origin differences certainly have an impact on the outcomes, and OECD countries vary in the origins of their humanitarian intakes. Thirdly, different groups of humanitarian migrants also have different labour market integration patterns. In particular, economic theory suggests that asylum-seekers - who account for the majority of the humanitarian intake in most European OECD countries, but not in Australia - should be a positively-selected group from the origin countries, mainly because they have to make their way into the country in which they are seeking asylum. This is confirmed by data from Germany on the employment status six months after completion of language courses, which suggest that accepted asylum seekers have higher employment rates than resettlers (OECD 2005b). Evidence from Canada shows that onshore refugees have higher initial earnings, but lower wage progression than humanitarian resettlers (Centre for International Statistics 1998).

118. Unfortunately, there is only limited information available on the labour market integration of the various groups of humanitarian migrants in Australia. Currently, only the LSIA and the Survey of Migrant Characteristics provide some information. This information is summarized in Table 10. 
Table 10: Available evidence on the employment outcomes of refugees and other humanitarian migrants in Australia, various years

\begin{tabular}{|c|c|c|c|c|c|c|}
\hline & \multicolumn{5}{|c|}{ LSIA } & \multirow{3}{*}{$\begin{array}{c}\text { Survey of Migrant } \\
\text { Characteristics }^{(1)} \\
2004\end{array}$} \\
\hline & \multicolumn{2}{|c|}{$\begin{array}{c}\text { six months after } \\
\text { arrival }\end{array}$} & \multicolumn{2}{|c|}{$\begin{array}{c}18 \text { months after } \\
\text { arrival }\end{array}$} & \multirow{2}{*}{$\begin{array}{c}2 \begin{array}{c}\text { months after } \\
\text { arrival }\end{array} \\
\sim 1998\end{array}$} & \\
\hline & $\sim 1995$ & $\sim 2000$ & $\sim 1996$ & $\sim 2001$ & & \\
\hline Refugees & $4 \%$ & $3 \%$ & $18 \%$ & $18 \%$ & $42 \%$ & $55 \%$ \\
\hline $\begin{array}{l}\text { Sponsored } \\
\text { Humanitarian } \\
\text { migrants (SHP) }\end{array}$ & $6 \%$ & $2 \%$ & $22 \%$ & $10 \%$ & $28 \%$ & $57 \%{ }^{(2)}$ \\
\hline
\end{tabular}

Note: 1. See Box 3 for the coverage of the Labour Force Status and Other Characteristics of Migrants Survey ("Survey of Migrant Characteristics"). 2. Data include onshore protection visa (i.e., accepted asylum seekers). This tends to skew the figures upward, since evidence from other OECD countries suggests that asylum seekers tend to have better employment outcomes than resettlers (see e.g. OECD 2005b).

119. Furthermore, aggregated data from the Survey of Migrant Characteristics (see Box 3 above) shows that humanitarian migrants have employment rates of $27 \%, 56 \%$ and $66 \%$ after up to five, six to ten, and more than eleven years of residence. Considering the difficult labour market integration of resettlers (who account for the vast majority of the humanitarian intake in Australia), these figures suggest relatively rapid labour market integration after a settlement period of about two to four years. Nevertheless, a significant gap in the employment rates compared to the native-born and other immigrant groups remains even after more than a decade in Australia. Figures reported for Canada show somewhat higher employment rates for humanitarian migrants (Centre for International Statistics 1998), but are not fully comparable due to a different composition of the refugee population.

120. It seems that the SHP migrants - i.e. humanitarian migrants who have some kind of sponsorship in Australia -fare worse in the labour market than refugees, at least in the medium to longer term. Regressions with the first cohort of the LSIA on the employment probability that control for a variety of socio-demographic factors do not yield any significant differences between refugees and SHP migrants shortly after arrival (see Annex 2d). ${ }^{50}$ However, the employment probability of SHP migrants after 48 months is almost $50 \%$ below that of refugees with the same socio-demographic characteristics.

121. It is difficult to pin down the reasons for these differences. One would expect that the links that SHP migrants have to Australian residents and/or institutions would facilitate their integration into the labour market. ${ }^{51}$ This does not appear to be the case. One reason might be the somewhat lower assistance level that SHP migrants have tended to have in the initial stages. Only recently have they obtained access to the full range of services as refugees, and initial settlement support is generally expected to be provided by the sponsor where they are able to do so. DIMA expects SHP migrants will experience greater labour market integration following the introduction of access to initial settlement support under the IHSS. Unfortunately, there are no programme data available, so it is difficult to assess which support measures

50. This is partly attributable to the fact that very few humanitarian migrants are in employment shortly after arrival.

51. Note that, for example, migrants in the skilled visa category who do have relatives in Australia need fewer points in the points system. 
have the largest impact on the integration of humanitarian immigrants. There is some information available from the LSIA, but the sample sizes are too small to isolate the impact of specific services. ${ }^{52}$

122. Migrant Resource Centres (MRC) address the question of the integration of humanitarian migrants through a long-term strategy on a local level, with the support of networks of the principal stakeholders (see Box 4). In a client satisfaction survey (Urbis 2003), it was observed that employment officers in MRCs were particularly valued by migrants to overcome barriers on the job market.

\section{Box 4: The activities of Migrant Resource Centres - an example from a Sydney suburb}

Migrant Resource Centres are locally-based community organisations that provide a broad range of services on a not-for-profit basis. These services are mainly targeted at humanitarian migrants and family-stream migrants with a low level of English proficiency in the first years after arrival. The Blacktown Migrant Resource Centre, located in a part of the Sydney metropolitan area in which about 1500 Sudanese refugees have been recently resettled, is one of about 30 centres which have been established in Australia since the late 1970s.

The Blacktown centre is run by a management board of volunteers which comprises representatives from ethnic organisations, mainstream services (employment services, local government, the police) and individuals from the local business community. Among the key activities are employment-related services for the rapidly growing community of humanitarian migrants from Sudan. From the outset, it was acknowledged by the Sudanese community and the local authorities involved that a key problem for social integration - and related to a rising incidence in crime - was a lack of employment opportunities, especially for young males.

An initial meeting with local employers was facilitated at the centre with members of the Sudanese community. Parallel to this, a Sudanese Employment Information Session was organised with Job Network providers and representatives of the relevant public agencies, which resulted in the development of a long-term strategy for employment and training. In addition, training pathways were developed with the establishment of an agriculture course at a local technical college, with one specialized member of the Sudanese community involved in the delivery of farming practices.

In Australia, in Blacktown as elsewhere, the involvement of local police officers in integration activities is noteworthy. In situations in which there is a concentration of migrants who may be difficult to integrate (such as refugees who have suffered gross human rights violations), the local police perceives this as a means of proactive crime prevention. The evidence from Blacktown suggests that bringing such migrants into employment with the support of the police can also be an effective strategy for social integration, particularly when the latter is impeded by lack of employment opportunities and frustration. It also helps to ensure acceptance of the activities and services with respect to migrant integration at the local level. Finally, police involvement in local integration efforts sends a signal to migrants that the police serves for the interests of the entire community.

123. Officials currently are looking on a whole-of-government basis at ways to improve the delivery of government services to humanitarian entrants, with a focus on improving health, education and employment outcomes by improved planning and early intervention services.

124. Given the relatively high budgetary cost associated with long-term unemployment, even a slightly higher overall employment probability of humanitarian migrants would have a notable budget impact. Analysis with the LSIA (see Annex 2d) suggests that early labour market entry has a strong and robust influence on employment 48 months later - similar to the results observed in Sweden (OECD 2004).

52. For example, in LSIA1, only for about 100 migrants in each of the two categories is there information on "help with looking for work" available, and the nature of this help is unspecified. 


\section{The outcomes of the second generation}

125. There are many reasons why one cannot necessarily expect, at least in the early years of settlement, outcomes for the foreign-born that match those of the native-born with the same socioeconomic characteristics. Among these are problems of the recognition of foreign qualifications and work experience; difficulties associated with living in a new country; language problems; etc. These impediments should, at least in principle, not play a role for the native-born children of foreign-born parents. For this group, one would expect outcomes that are similar to those of their native-born peers without a migration background that have a comparable socio-economic background. For these reasons, the outcomes of the second generation can be viewed as the "benchmark" for the long-term success of integration policy.

126. About 25\% of the native-born population in Australia have at least one parent who is foreignborn, and about $10 \%$ have both parents foreign-born (the so-called "second generation"). Although there are no comparable data available on the share of the second generation in the total population, data from the OECD-PISA study on the place of birth of the parents of 15-year-old students suggests that on this basis, Australia ranks second among OECD countries, with only Luxembourg having a higher share. Notwithstanding the size of this population, there has been relatively little study of the labour market integration of this group in Australia thus far.

127. The limited available evidence suggests that the labour market integration of the second generation is not a major issue in Australia, as the outcomes are quite positive - in contrast to what is observed in many European OECD countries. With the recently-established Household, Income and Labour Dynamics Australia survey, an analysis of the current labour market integration of the second generation is possible. They have, on average, a higher educational attainment than the children of nativeborn, and somewhat more favourable employment and unemployment rates (Table 11). Also after controlling for age, gender, educational attainment and marital status, there are in most specifications no significant differences in the employment probability between the second generation and the native-born. ${ }^{53}$ These observations also broadly hold for those of the second generation whose parents are from nonOECD countries.

Table 11: Outcomes of the second generation, 2003, 25-36 years old

\begin{tabular}{c|ccc}
\hline & $\begin{array}{c}\text { native-born without } \\
\text { migration background }\end{array}$ & $\begin{array}{c}\text { second } \\
\text { generation }\end{array}$ & $\begin{array}{c}\text { second generation - } \\
\text { both parents non-OECD }\end{array}$ \\
\hline Share of highly-qualified & $35 \%$ & $46 \%$ & $49 \%$ \\
Employment rate & $76 \%$ & $83 \%$ & $85 \%$ \\
Unemployment rate & $5 \%$ & $(2 \%)$ & $\ldots$ \\
\hline
\end{tabular}

Note: 1. Highly-qualified are classified as having a diploma/certificate or above. There are no specifications on the nature of the certificate available.

Source: Calculations based on the Household, Income and Labour Dynamics in Australia Survey.

128. With respect to the educational outcomes, there is internationally comparable data available from the OECD’s Programme for International Student Assessment (PISA) (Table 12). These data suggest that Australia's second generation fares well in international comparison: there are no significant differences in

53. An analysis which controls for the parents' educational background is unfortunately not possible. This information will become available with wave 5 of the Household, Income and Labour Dynamics Australia Survey (expected early 2007). 
the mathematics and reading literacy scores between the second generation and the offspring of nativeborn. This is doubtlessly partly attributable to the fact that Australia's immigration policy - like that of Canada, which has also favourable outcomes - has been skills focused for a long time (see Tables 3 and 6). Khoo et al. (2002), based on data from the 1996 census, report that the second-generation's parents are more qualified than parents who are native-born, in contrast to the situation in most European countries. The PISA data and other research have shown some tendency towards intergenerational transmission of human capital, with school systems often being limited in their ability to attenuate this. However, even after allowing for such structural differences, there are only three countries in the PISA study in which the outcomes for the second generation seem to be at least as good as for the offspring of the native-born: Canada, the United States and Australia.

Table 12: Points differences in the PISA (2003) scores of natives and the second generation, children aged 15 years

\begin{tabular}{l|cc|cc}
\hline & \multicolumn{2}{|c|}{$\begin{array}{c}\text { Before accounting for the effects of } \\
\text { socio-economic background of students }\end{array}$} & \multicolumn{2}{c}{$\begin{array}{c}\text { After accounting for the effects of } \\
\text { socio-economic background of students }\end{array}$} \\
\hline & Mathematics & Reading & Mathematics & Reading \\
\hline Australia & $\mathbf{0}$ & $\mathbf{0}$ & $\mathbf{0}$ & $\mathbf{0}$ \\
Canada & 0 & 10 & -8 & 12 \\
United States & 22 & 22 & 0 & 0 \\
New Zealand & 32 & 22 & 16 & 0 \\
France & 48 & 48 & 14 & 0 \\
Austria & 56 & 73 & 26 & 31 \\
Netherlands & 59 & 50 & 36 & 22 \\
Switzerland & 59 & 53 & 36 & 32 \\
Denmark & 70 & 57 & 47 & 0 \\
Belgium & 92 & 84 & 45 & 40 \\
Germany & 93 & 96 & & 48 \\
\hline
\end{tabular}

Note: "o" indicates that the gap is not statistically significant. The socio-economic background was created on the basis of the following variables: the International Socio-Economic Index of Occupational Status (ISEI), the highest level of education of the student's parents (converted into years of schooling), the index of family wealth, the index of home educational resources and the index of possessions related to "classical culture" in the family home. For each test, the mean score across all OECD countries was set at 500 points, with a standard deviation of 100 points (see OECD 2004 for details).

Source: Secretariat calculations based on the OECD PISA database.

129. This suggests that the relatively positive nature of the public discourse on immigration, and the settlement and integration perspective given to migrants and their offspring in these countries, may well have a positive impact on the education and labour market outcomes of the second generation. Economic theory suggests that the negative public discourse and the corresponding insecurity in the migrant status in some European countries may reduce incentives to invest in human capital in general and host-country human capital (such as e.g. language) in particular. This may also have an important effect on outcomes for the second generation.

130. In contrast, Le and Miller (2002), based on the Longitudinal Survey of Australian Youth, find after controlling for the socio-economic background of the parents that individuals having at least one parent born in a non-English-speaking country have about three and a half months more schooling than comparable children with an English-speaking background. This finding is generally attributed to the fact that immigrants in Australia, particularly Asian ones, have high aspirations for their offspring (see e.g. Khoo et al. 2002). 


\section{SUMMARY AND RECOMMENDATIONS}

\author{
Australia has \\ relatively favourable \\ overall labour \\ market outcomes for \\ immigrants...
}

...which are assisted by its long tradition as an immigration country...

....and the skilled nature of its immigrant intake.

Selection policy has an impact even when other characteristics are controlled for.
Compared to most other OECD countries, Australia has favourable overall outcomes for immigrants. Employment of immigrant men is high, and unemployment rates of immigrants are among the lowest in the OECD, both in absolute terms and relative to the native-born. Immigrants are also less affected by long-term unemployment than the native-born, in contrast to what is observed in other OECD countries.

Australia is, after Luxemburg, the OECD country with the highest share of immigrants in the total population. Since the end of World War II, it has developed a pro-active and selective immigration policy. Initially, immigration was mainly from the United Kingdom, which still accounts for almost one quarter of the immigrant population. Since the 1950s, Australia's immigrant intake has diversified greatly, first to other European countries, and later mainly to Asian countries. With this diversification, integration of immigrants emerged as a topical issue. Australia established an anti-discrimination law as early as 1975, and integration of all immigrants - regardless of origin - is now viewed as part of the national heritage. There is a strong emphasis on the economic benefits deriving from Australia's multicultural population structure. Citizenship take-up is already possible after two years of settlement - the shortest period in the OECD - and actively promoted as a means of integration.

The favourable labour market outcomes of immigrants in Australia are clearly assisted by the socio-economic characteristics of its immigrant intake. The immigrant population has a higher educational attainment on average than the native-born. Since 1966, applications for settlement have been judged inter alia on the basis of the potential migrant's qualifications, and a points system applies for skilled migrants who account for the majority of the immigrant intake - since 1979. As the migrant intake diversified towards non-English-speaking countries - in particular from Asia the initial selection system was seen to be failing to ensure labour market integration of skilled migrants from non-English-speaking countries. As a result, selection policy was tightened, and the number of skilled migrants has been increased. Job-ready English is now a requirement. Furthermore, immigration now favours people with Australian qualifications, particularly benefiting foreign students studying in Australia. Forty-five per cent of all immigrants have English as their first language, and more than half of the current immigrant intake under the General Skilled Migration stream has Australian qualifications. These characteristics clearly facilitate integration into the Australian labour market. However, the impact of Australian qualifications does not appear to be very strong compared to sufficient mastery of English.

Selection policy not only has an impact on the socio-economic characteristics of the migrant intake. Even after controlling for a wide range of observed socio-economic characteristics, immigrants who arrived as principal applicants under the skilled migrant category perform significantly better than family migrants and humanitarian migrants. One explanation for this outcome is the fact that skilled migrants are a positively self-selected group, which appear to be highly motivated to improve their economic situation. Furthermore, their English proficiency and their qualifications 
have been formally assessed, which enhances transparency for potential employers.

The settlement perspective is likely to foster favourable results.

\section{Participation of immigrant women is relatively low.}

\section{Immigrants from English-speaking countries perform better than the native-born.}

A distinguishing feature of Australia's immigration policy with respect to many European OECD countries is the settlement perspective. All groups of non-temporary migrants get a permanent permit upon entry. There are a variety of services and symbolic measures in place to convey a message to immigrants that they are welcome and expected to stay. This settlement perspective is not only important with respect to the growing international competition for highly skilled migrants whom Australia seeks to attract. The longer horizon also increases incentives to invest in host-countryspecific human capital. It can therefore be expected to contribute to the integration of immigrants, although this impact is difficult to quantify.

In contrast to the situation for immigrant men, the employment of immigrant women is not high in international comparison. As their unemployment is also low, participation in the labour market per se seems to be a problem.

A notable finding from Australia is the fact that immigrants from English-speaking OECD countries have even better outcomes than the native-born, on almost all labour market integration indicators.

Since the end of the "White Australia" policy in the early 1970s, immigration is mainly from non-OECD countries. These immigrants now account for the majority of both the immigrant stock and inflow. Despite the fact that they tend to be higher qualified than immigrants from the OECD area, their labour market outcomes are somewhat below those of other immigrants. This is, however, to some degree a cohort effect, since they are overrepresented among recent arrivals. Indeed, there is some evidence that their outcomes converge more rapidly to those of the native-born than those from non-English-speaking OECD countries. However, initial gaps in the employment rates of this group vis-à-vis the native-born are relatively high.

Overqualification is a problem...
Given the high skills component of Australia's immigration intake, it is of key importance to made adequate use of immigrants' human capital. "Overqualification" (i.e. people holding a job that requires lesser qualifications than would theoretically be available to them, given their level of education) is a problem, although it does not per se appear to be more present in Australia than in other OECD countries. However, highly qualified immigrants from non-OECD countries are particularly affected by occupational downgrading in Australia, and this group is growing in numbers. Almost forty per cent of employed highly qualified immigrants from these countries only work in low- and medium skilled jobs. 


\author{
...despite the \\ elaborate systems of \\ skills recognition in \\ place.
}

The waiting period for skilled migrants may have aggravated the problem.

Work placements in skilled jobs should be more broadly available.

There is a need for better information on skills recognition.
One way of tackling the problem of occupational downgrading is the recognition of foreign qualifications and experience, and data suggest that overqualification may be mainly a problem for migrants who do not have their qualifications recognised. Awareness of recognition-related labour market integration problems dates back to the late 1960s, and skilled migrants now need to have their qualifications assessed prior to application. Although fairly elaborate, this assessment does not ensure full recognition of occupational qualifications, since these are often regulated at the State level. The Council of Australian governments has started a process to overcome such obstacles by December 2008 for the trades.

Since 1997, skilled immigrants do not have access to income support and social security benefits for the first two years after arrival. Research suggests that this has incited them to take up a job more quickly, but that they seem to be less likely to end up in a job which uses their prior qualifications. Almost fifty per cent of the employed highly qualified recent arrivals are in a job below their qualification level. Further study is warranted to see if this initial occupational downgrading of immigrants has any long-lasting negative effects in their career prospects, and how this is to be weighted against potentially offsetting positive effects of earlier labour market entry on the employment probability. If there are strong long-lasting negative effects, it would make a case for reconsidering the waiting period.

Due to the two-year waiting period which results in a lack of access to active labour market measures, there are no programmes in place which target the problem of overqualification at the federal level. Evidence in some States which have provided such programmes suggests that unpaid work placements in skilled jobs, combined with training, are both an effective and cost-efficient way of tackling this problem. However, these are relatively small-scale at the moment. Broader targeted provision should be considered.

Skilled immigrants do not always seem to be aware of recognition-related problems which hinders their chances of finding jobs which match their qualifications, despite the fact that the assessing authorities are obliged to inform them about potential further requirements after entry. There is anecdotal evidence that this lack of awareness has lead to some frustration among recent arrivals. Greater transparency for migrants about the additional requirements they will have to meet if they want employment in a particular State and profession would be desirable. First steps have been taken by the recent launch of a website on skills assessment and recognition procedures.

In contrast to the basically self-funded nature of skilled and family migration, immigrants under the humanitarian programme (10\% of total immigration) receive relatively generous integration support, including pre-embarkation orientation. Based on an initial needs assessment, there is a broad range of services available, which are generally provided by community-based organisations. Funding for these services is given on the basis of competitive tenders, which oblige the service providers to meet certain outcome requirements. However, later successful labour market integration is not part of these requirements, since labour-market integration support is expected to be provided by employment services. Accordingly, there are no financial incentives for the contractors of settlement services to provide labour-market-oriented support (with the exception of referral to the employment services). Introduction of 
employment-oriented outcome indicators, ideally in the long run, should be considered. Migrant Resource Centres could also be incited to provide targeted labour market integration support via specialised employment officers.

The low employment outcomes of sponsored humanitarian migrants warrant further assessment.

The effectiveness of English-language training needs to be assessed.

The effectiveness of labour market services needs to be investigated.

\section{Discrimination may be less a problem under the current favourable economic environment, but vigilance is warranted.}

About half of the current humanitarian intake in Australia consists of resettlers who have some kind of sponsorship in Australia. One would expect these migrants to have better outcomes than refugees, as the former should have access to networks, etc. which refugees do not have. Despite this, sponsored humanitarian immigrants seem to do less well in the labour market than refugees. One possible explanation for this is that sponsored humanitarian immigrants originally did not have access to all initial settlement services like formal refugees. Although sponsored migrants now have formal access to most services, initial settlement support is still expected to be generally provided by the sponsors where they are able to do so. The links between this somewhat more limited integration support and the lower employment of this group should be subject to further investigation. It is expected that SHP migrants will experience greater labour market integration following the introduction of access to initial settlement support under the IHSS. In this context, it should be noted that the Australian authorities are currently investigating on a whole-of-government basis ways to improve the delivery of government services to humanitarian entrants.

Australia was among the first countries in the world to provide language training to immigrants with the explicit aim of fostering labour market and social integration. In addition, Australia operates elaborate Translation and Interpretation Services, which can assist immigrants in daily life, anytime. Language training accounts for the bulk of federal expenses on integration, and is provided in a relatively elaborate, multitiered and modular structure. Immigrants with no prior knowledge of English are eligible for 910 hours of language training, humanitarian immigrants for even more. However, there may be some trade-off between length of formal training and earlier entry into the labour market. Yet, with currently available data, it is not possible to fully analyse the effectiveness of language training. Some programme data seem to exist, but they do not appear to be made available to researchers. A high priority should be assigned to evaluating what kinds of language training and how much best contribute to labour market integration

Only highly aggregated information is available on the relative participation and outcomes of immigrants with respect to the labour market services provided by the Job Network. In order to analyse the effectiveness of these services with respect to immigrants' labour market integration, more disaggregated information would be needed. Some of this seems to exist, but the information is not made available to researchers outside Australia. A further investigation of the effectiveness of the Job Network services with respect to the labour market integration of immigrants seems warranted.

Under the currently tight labour market, discrimination in hiring practices does not seem to be a major problem for most immigrants. Nevertheless, immigrants from non-OECD countries are particularly affected by occupational downgrading and lower returns to their qualifications - despite the pre-application qualification assessment for skilled migrants. This is a potential concern since migrants from these countries account for a growing part of the immigrant population. Without a common measure of human capital, it is, however, difficult to assess to which degree these problems are attributable to discrimination. Some vigilance with respect to 
discrimination seems warranted, here as in other countries, particularly if labour market conditions were to worsen.

The labour market integration of the second generation has been quite successful.
In many ways, the outcomes of the second generation can be viewed as the "benchmark" for the long-term success of integration policy, since migration-related labour market impediments such as lower language proficiency or non-recognition of qualifications or of experience should, in principle, not operate for the children of immigrants who were born in Australia. The available evidence shows that with respect to both educational attainment and employment, the second generation in Australia is well integrated in international comparison. Their outcomes tend to be better than those of children of the native-born. 


\section{Annex 1: Australian migration categories, fiscal year 2004-2005}

\begin{tabular}{|c|c|c|c|c|c|}
\hline Category & Description & Offshore & Onshore & Total & $\begin{array}{c}\text { \% of } \\
\text { intake }\end{array}$ \\
\hline $\begin{array}{l}\text { Spouse/ Interde- } \\
\text { pendency/ Fiancé }\end{array}$ & $\begin{array}{l}\text { partners of an Australian permantent resident or citizen, } \\
\text { including fiancés and same-sex partners }\end{array}$ & 18,440 & 9,170 & 27,610 & $22 \%$ \\
\hline Child & children and adoptions under 25 and dependent & 2,280 & 210 & 2,490 & $2 \%$ \\
\hline Parent & $\begin{array}{l}\text { sponsored by an Australian citizen or permanent resident } \\
\text { with more than } 2 \text { years prior residence, need of assurance of } \\
\text { support for at least } 2 \text { years. Most places allocated to the } \\
\text { contributory parent category, where substantially higher } \\
\text { application charges apply }\end{array}$ & 3,800 & 700 & 4,500 & $4 \%$ \\
\hline $\begin{array}{l}\text { Preferential/ Other } \\
\text { Family }\end{array}$ & $\begin{array}{l}\text { under certain conditions: aged dependent relatives, } \\
\text { remaining relatives or carer of an Australian citizen or } \\
\text { permanent resident }\end{array}$ & 1,210 & 480 & 1,690 & $1 \%$ \\
\hline \multicolumn{2}{|l|}{ Total Family } & 31,170 & 10,570 & 41,740 & $33 \%$ \\
\hline $\begin{array}{l}\text { Employer nomination, } \\
\text { labour agreement and } \\
\text { regional schemes }\end{array}$ & $\begin{array}{l}\text { based on nomination or sponsorship of Australian } \\
\text { employers or states/territories if it is proven that vacancies } \\
\text { cannot be filled (for specific jobs) or skills are in local } \\
\text { demand (independent of a specific job - i.e. a preferential } \\
\text { points scheme); additional passmarks (below 45, vocational } \\
\text { English, experience, etc.) to be met }\end{array}$ & 6,620 & 10,540 & 17,160 & $13 \%$ \\
\hline Business & for business owners, senior executives and investors & 3,230 & 1,590 & 4,820 & $4 \%$ \\
\hline Distinguished talents & $\begin{array}{l}\text { for individuals with an internationally-recognised record of } \\
\text { exceptional and outstanding achievement }\end{array}$ & 80 & 100 & 190 & $0 \%$ \\
\hline Skilled independent & $\begin{array}{l}\text { points-based assessment based inter alia on age, English } \\
\text { language and qualifications }\end{array}$ & 26,460 & 14,720 & 41,180 & $32 \%$ \\
\hline $\begin{array}{l}\text { Skilled Australian } \\
\text { sponsored }\end{array}$ & $\begin{array}{l}\text { points-based assessment, preferential scheme for migrants } \\
\text { with family links to Australian residents (brothers, nieces, } \\
\text { etc.) }\end{array}$ & 12,720 & 1,800 & 14,530 & $11 \%$ \\
\hline \multicolumn{2}{|l|}{ Total Skills } & 49,120 & 28,760 & 77,880 & $61 \%$ \\
\hline Special Eligibility & for former residents & 170 & 280 & 450 & $0 \%$ \\
\hline \multicolumn{2}{|c|}{ Total Non-humanitarian } & 77,670 & 36,690 & 114,360 & $90 \%$ \\
\hline Refugee & $\begin{array}{l}\text { resettlers subject to persecution in their home country and } \\
\text { identified in co-operation with the UNHCR }\end{array}$ & 5,511 & & 5,511 & $4 \%$ \\
\hline $\begin{array}{l}\text { Special Humanitarian } \\
\text { Programme (SHP) }\end{array}$ & $\begin{array}{l}\text { resettlers who suffered gross violation of human rights in } \\
\text { their home country but do not qualify as refugees under the } \\
\text { UNHCR definition; need to be supported by an Australian } \\
\text { permanent resident/citizen or an Australian organisation }\end{array}$ & 6,585 & 170 & 6,755 & $5 \%$ \\
\hline Permanent protection & accepted asylum seekers who arrived legally in Australia & & 662 & 662 & $0 \%$ \\
\hline \multicolumn{2}{|l|}{ Total humanitarian } & 12,096 & 832 & 12,928 & $10 \%$ \\
\hline \multicolumn{2}{|l|}{ Grand total } & 89,766 & 37,522 & 127,288 & $100 \%$ \\
\hline
\end{tabular}

Notes: Planning levels and numerical limits apply for each category. Figures include principal and secondary applicants (i.e. accompanying family). In addition, 602 permanent visas were granted to residents from New Zealand. There are also 250 other onshore grants, which include humanitarian visas granted directly by ministerial intervention as well as temporary humanitarian visas. DIMA counts these as part of the Humanitarian Programme, which thus results in a total of 13,178.

Source: DIMA. 
Annex 2a: Logistic regression on the likelihood of employment relative to non-employment of immigrants 48 months after arrival, first cohort, Longitudinal Survey of Immigrants to Australia

Model 1

Model 2

Model 3

Coeff.

Sign.

Coeff.

Sign.

Coeff.

Sign.

Employed six months after arrival

$\begin{array}{cc}1.542 & 0.00 \\ (0.009) & 0.91\end{array}$

Tertiary education

(0.009)

0.91

$(-0.005)$

1.516

0.000

Basic education

Age-group 25 to 34

$(-0.150)$

0.14

$-0.222$

0.96

$0.267 \quad 0.01$

0.385

0.05

$(-0.144)$

0.11

Age-group 35 to 44

0.414

0.00

0.443

0.00

0.265

0.01

Age-group 45 to 54

$-0.668 \quad 0.00$

$-0.724$

0.00

0.412

0.00

Age-group 55 to 64

$-2.167$

0.00

$-2.177$

0.00

$-0.672$

0.00

Male

$1.191 \quad 0.00$

1.214

0.00

$-2.169$

0.00

Married

$-0.185 \quad 0.06$

(-0.166)

0.00

1.192

0.00

Skilled Migrant - Principal Applicant

0.776

0.00

0.573

0.14

$-0.177$

0.07

$-0.199$

0.05

$-0.250$

0.00

0.765

0.00

Humanitarian Visa

English spoken at least well at arrival

0.611

0.553

0.02

$-0.192$

0.06

Australian post-secondary

qualifications

0.00

0.00

0.594

0.00

(0.181)

0.49

Post-secondary qualifications from another English-speaking country

(0.131)

0.27

Note: Sample restricted to immigrants aged 15 to 64. Model 2 is also restricted to people not in employment in the first wave. A higher magnitude of the coefficient implies a stronger influence. The significance level indicates the probability that the true influence is zero (i.e. no impact). Coefficients that are not significant at the ten percent level are in parentheses. The models include a constant. Alternative models (not shown) confirmed the robustness of the results. 


\section{Annex 2b: Logistic regression on the likelihood of employment relative to non-employment of immigrants, Household, Income and Labour Dynamics Australia Survey 2003}

\begin{tabular}{|c|c|c|c|c|}
\hline & Coefficient. & $\begin{array}{l}\text { Level of } \\
\text { significance }\end{array}$ & Coeff. & Sign \\
\hline Australian post-school qualifications & 0.286 & 0.06 & 0.590 & 0.00 \\
\hline $\begin{array}{l}\text { Post-secondary qualifications from other } \\
\text { English-speaking countries }\end{array}$ & & & 0.764 & 0.00 \\
\hline Tertiary education & 0.641 & 0.00 & 0.684 & 0.00 \\
\hline Basic education & -0.615 & 0.00 & $(-0.609)$ & 0.15 \\
\hline Male & 0.825 & 0.00 & 0.920 & 0.00 \\
\hline Age-group 25 to 34 & 0.647 & 0.00 & 0.603 & 0.03 \\
\hline Age-group 35 to 44 & $(0.262)$ & 0.25 & $(0.322)$ & 0.25 \\
\hline Age-group 45 to 54 & $(0.425)$ & 0.10 & 0.546 & 0.07 \\
\hline Age-group 55 to 64 & -0.808 & 0.01 & -0.751 & 0.03 \\
\hline Married & 0.228 & 0.08 & $(0.129)$ & 0.36 \\
\hline Years-of-residence & $(0.011)$ & 0.11 & $(0.012)$ & 0.10 \\
\hline English spoken at least well & 1.499 & 0.00 & 1.518 & 0.00 \\
\hline Born in an OECD-English-speaking country & 0.371 & 0.00 & & \\
\hline
\end{tabular}

Note: Sample restricted to immigrants aged 15 to 64 . The model includes a constant. There is some correlation between Australian post-school qualifications (or qualifications from other English-speaking countries) and having a tertiary education. Using age at immigration as an instrument and adapting the model accordingly does not qualitatively alter the results. Alternative models (not shown) confirmed the robustness of the results. For the interpretation of the results, see the Note to Annex 2a.

Annex 2c: Logistic regression on the likelihood of employment relative to non-employment of immigrants 48 months after arrival, first cohort, Longitudinal Survey of Immigrants to Australia

\begin{tabular}{l|cc|cc|cc} 
& \multicolumn{2}{c}{ Model 1 } & \multicolumn{2}{c}{ Model 2} & \multicolumn{2}{c}{ Model 3 } \\
& Coeff. & \multicolumn{1}{c}{ Sign. } & Coeff. & Sign. & Coeff. & Sign. \\
\hline Employed six months after arrival & 0.975 & 0.00 & & & & \\
Tertiary education & $(-0.159)$ & 0.31 & $(-0.101)$ & 0.54 & $(0.063)$ & 0.92 \\
Basic education & $(-0.091)$ & 0.58 & $(-0.115)$ & 0.51 & $(0.819)$ & 0.27 \\
Age-group 25 to 34 & 0.775 & 0.00 & 0.811 & 0.00 & $(-0.285)$ & 0.70 \\
Age-group 35 to 44 & 0.821 & 0.00 & 0.777 & 0.00 & $(0.792)$ & 0.37 \\
Age-group 45 to 54 & $(-0.319)$ & 0.22 & $(-0.331)$ & 0.23 & $(-0.739)$ & 0.52 \\
Age-group 55 to 64 & -3.136 & 0.00 & -3.158 & 0.00 & $(-21.809)$ & 0.99 \\
Male & 1.046 & 0.00 & 1.062 & 0.00 & $(0.858)$ & 0.15 \\
Married & -0.393 & 0.02 & -0.367 & 0.05 & $(-0.971)$ & 0.15 \\
Attending an English course six months & & & & & & \\
after arrival & $(0.454)$ & 0.10 & 0.885 & 0.01 & $(-0.649)$ & 0.29
\end{tabular}

Note: Sample restricted to immigrants aged 15 to 64 who do not speak English at least well six months after arrival. Model 2 is also restricted to people not in employment in the first wave, and Model 3 to those who are in employment at wave one. A higher magnitude of the coefficient implies a stronger influence. The significance level indicates the probability that the true influence is zero (i.e. no impact). Coefficients that are not significant at the ten percent level are in parentheses. The models include a constant. Alternative models (not shown) confirmed the robustness of the results. 
Annex 2d: Logistic regression on the likelihood of employment relative to non-employment of humanitarian immigrants, six and $\mathbf{4 8}$ months after arrival, first cohort, Longitudinal Survey of Immigrants to Australia

\begin{tabular}{l|cc|cc} 
& \multicolumn{2}{c}{ Model 1} & \multicolumn{2}{c}{ Model 2} \\
& Coeff. & Sign. & Coeff. & Sign. \\
\hline Employed six months after arrival & & & 1.581 & 0.00 \\
Tertiary education & $(-0.212)$ & 0.651 & $(0.102)$ & 0.24 \\
Basic education & $(-0.365)$ & 0.511 & -0.189 & 0.07 \\
Age-group 25 to 34 & 1.331 & 0.069 & 0.329 & 0.00 \\
Age-group 35 to 44 & 1.895 & 0.021 & 0.499 & 0.00 \\
Age-group 45 to 54 & $(-1.601)$ & 0.607 & -0.635 & 0.00 \\
Age-group 55 to 64 & $(-16.501)$ & 0.999 & -2.198 & 0.00 \\
Male & 1.451 & 0.012 & 1.362 & 0.00 \\
Married & -1.246 & 0.008 & -0.347 & 0.00 \\
Special Humanitarian Programme & $(0.409)$ & 0.305 & -1.115 & 0.00 \\
English spoken at least well at arrival & 0.745 & 0.089 & 0.698 & 0.00
\end{tabular}

Note: Sample restricted to refugees and special humanitarian programme migrants aged 15 to 64 . The dependent variable in Model 1 is employment six months after arrival, whereas the dependent variable in Model 2 is employment 48 months after arrival. The models include a constant. Alternative models (not shown) confirmed the robustness of the results. 


\section{BIBLIOGRAPHY}

Auchmuty, James (1970), Report by the Commonwealth Advisory Committee on the Teaching of Asian Languages and Cultures in Australia.

Aydemir, Abdurrahman; Skuterud, Mikal (2005), “Explaining the deteriorating entry earnings of Canada's immigrant cohorts, 1966-2000”. Canadian Journal of Economics, 38 (2), 641-671.

Betts, Katharine (2003), “Immigration policy under the Howard government”. Australian Journal of Social Issues, 38 (2), 169-192.

Centre for International Statistics (1998), “The Changing Labour Market Prospects of Refugees in Canada”. Citizenship and Immigration Canada, Ottawa.

Chiswick, Barry; Lee, Yew L.; Miller, Paul W. (2005a), "Longitudinal Analysis of Immigrants Occupational Mobility: A Test of the Immigrant Assimilation Hypothesis”. IZA Working Paper No. 452.

Chiswick, Barry, Lee, Yew L.; Miller, Paul W. (2005b), “Immigrant Earnings: A Longitudinal Analysis”. International Migration Review, 39 (2), 332-353

Cobb-Clark, Deborah (2001), “The longitudinal Survey of Immigrants to Australia”. The Australian Economic Review, 34 (4), 467-477.

Constant, Amelie; Schultz-Nielsen, Marie Louise (2004), “Immigrant Selection and Earnings”. In: Tranaes, Torben and Zimmermann, Klaus (eds.): Migrants, work and the welfare state. University Press of Southern Denmark and Rockwool Foundation, 187-211.

Committee of Inquiry into the Recognition of Overseas Qualifications (1983), "The Recognition of overseas qualifications in Australia: report of the Committee of Inquiry”. Australian Government Publishing Service, Canberra.

DEWR (2005), “Labour Market Assistance Outcomes. Year ending December 2004”. Department of Employment and Workplace Relations, Canberra.

DIMIA (2005), “Portfolio budget statements 2005-2006”. Department of Immigration and Multicultural and Indigenous Affairs, Canberra.

DIMIA (2003a), “Multicultural Australia: United in Diversity”. Department of Immigration and Multicultural and Indigenous Affairs, Canberra.

DIMIA (2003b), "Report of the Review of Settlement Services for Migrants and Humanitarian Entrants". Department of Immigration and Multicultural and Indigenous Affairs, Canberra. 
DIMIA (2001), “Immigration. Federation to century’s end 1901-2000”. Department of Immigration and Multicultural and Indigenous Affairs, Canberra.

DIMIA (1989), "National Agenda for a Multicultural Australia”. Department of Immigration and Multicultural and Indigenous Affairs, Canberra.

Ferrer, Ana; Green, David A.; Riddell, W. Craig (2006), “The effect of literacy on immigrant earnings”. Journal of Human Resources, 41 (2), 380-410.

Green, David; Worswick, Christopher (2002), "Earnings of immigrant men in Canada: the roles of labour market entry effects and returns to foreign experience". Citizenship and Immigration Canada, mimeographed.

Hawthorne, Lesleyanne (2005), “'Picking Winners': The recent transformation of Australia's Skilled Migration Policy”. International Migration Review, forthcoming.

Hawthorne, Lesleyanne (2002), “Qualifications recognition reform for skilled migrants in Australia: applying competency-based assessment to overseas-qualified nurses”. International Migration, 40 (6), 55-91.

Hugo, Graeme (2004), “Integration of Immigrants into the Labour Market in Australia”. Report for the OECD Working Party on Migration.

Ingram, David (2003), “English Language Policy in Australia”. Paper to the 2003 Summer International Conference of the Korea Association of Teachers of English.

Junankar, Raja P.N.; Mahuteau, Stéphane (2005), “Do migrants get good jobs?” New migrant settlement experience in Australia. Economic Record, 81 (255), S34-S46.

Junankar, Raja P.N.; Paul, Satya; Yasmeen, Wahida (2004), “Are Asian Migrants Discriminated Against in the Labour Market? A Case Study of Australia”. IZA Working Paper No. 1167.

Jupp, James (1995), “From "White Australia” to "part of Australia”: Recent shifts in Australian Immigration Policy Towards the Region”. International Migration Review, 29 (109), 207-228.

Kelly, Ross; Lewis, Phil; Mulvey; Charles; Dalzell, Brian (2002), “A Study to Better Assess the Outcomes in the New Enterprise Incentive Scheme”. Report prepared for the Department of Employment and Workplace Relations. Centre for Labour Market Research, University of Western Australia.

Khoo, Siew-Khan; McDonald, Peter; Giorgas, Dimi; Birrell, Bob (2002), "Second generation Australians. Report for the Department of Immigration and Multicultural and Indigenous Affairs”. Department of Immigration and Multicultural and Indigenous Affairs, Canberra.

Kler, Parvinder (2005), “Graduate Overeducation in Australia: A Comparison of the Mean and Objective Methods”. Education Economics, 13 (1), 47-72.

Le Grand, Carl; Szulkin, Ryszard (2002), "Permanent Disadvantage or Gradual Integration: Explaining the Immigrant-Native Earnings Gap in Sweden”. Review of Labour Economics \& Industrial Relations, 16 (1), 37-64. 
Le, Anh T.; Miller, Paul (2002), "Educational attainment in Australia: a cohort analysis. Longitudinal Survey of Australian Youth Research Report No. 25”. Australian Council for Educational Research, Camberwell.

Nahid, Asifa; Shamsuddin, Abul (2001), "Immigration and the unemployment benefit programme in Australia”. Applied Economics, 33, 1587-1597.

OECD (2005a), Trends in International Migration. 2004 Edition. OECD, Paris.

OECD (2005b), “The labour market integration of immigrants in Germany”. OECD, Paris. DELSA/ELSA/WP2(2005)3/REV1.

OECD (2005c), "Level of education of immigrants and the labour market: estimating the prevalence of overeducation”. OECD, Paris. DELSA/ELSA(2005)12.

OECD (2004), “The integration of immigrants into the labour market: the case of Sweden”. OECD, Paris. DELSA/ELSA(2004)13.

OECD (2003), OECD Economic Surveys - Australia. OECD, Paris.

OECD (2001), Innovations in labour market policies - the Australian way. OECD, Paris.

Richardson, Sue; Lester, Laurence (2004), “A Comparison of Australian and Canadian Immigration Policies and Labour Market Outcomes”. Report to the Department of Immigration and Multicultural Affairs. Department of Immigration and Multicultural Affairs, Canberra.

Richardson, Sue; Robertson, Frances; Ilsey, Diana (2001), “The Labour Force Experience of New Migrants”: Report to the Department of Immigration and Multicultural Affairs. National Institute of Labour Studies, Adelaide.

Richardson, Sue; et al. (2004), "The changing labour force experience of new migrants. Inter-wave comparisons for cohort 1 and 2 of the LSIA”. Report to the Department of Immigration and Multicultural Affairs. National Institute of Labour Studies, Adelaide.

Statistics Canada (2005), Longitudinal Survey of Immigrants to Canada. A portrait of early settlement experiences. Statistics Canada, Ottawa.

Thapa, Prem J. (2004), “On the risk of unemployment: a comparative assessment of the labour market success of migrants in Australia”. Australian Journal of Labour Economics, 7 (2), 199-229.

Urbis (2003), “A “client survey” on the effectiveness of DIMIA-funded community settlement services”. Department of Immigration and Multicultural and Indigenous Affairs, Canberra.

Voon, Derby and Miller, Paul (2005), "Undereducation and overeducation in the Australian labour market”. The Economic Record, 81 (255), S22-S33.

York, Barry (2003), “Australia and Refugees, 1901-2002: An Annotated Chronology Based on Official Resources”. Department of the Parliamentary Library Chronology No. 2 2002-03, Canberra.

Zubrzycki, Jerzy (1968), The Questing Years. Australian Government Publishing Service, Canberra. 


\section{OECD SOCIAL, EMPLOYMENT AND MIGRATION WORKING PAPERS}

Most recent releases are:

No. 48 THE INTEGRATION OF IMMIGRANTS INTO THE LABOUR MARKET: THE CASE OF SWEDEN (2007) Georges Lemaître

No. 47. THE LABOUR MARKET INTEGRATION OF IMMIGRANTS IN GERMANY (2007) Thomas Liebig

No. 46 MINIMUM WAGES, MINIMUM LABOUR COSTS AND THE TAX TREATMENT OF LOW-WAGE EMPLOYMENT (2007)

Herwig Immervoll

No. 45 PUBLICLY PROVIDED SERVICES AND THE DISTRIBUTION OF RESOURCES (2006)

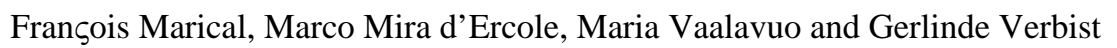

No. 44 THE TURKISH PENSION SYSTEM: FURTHER REFORMS TO HELP SOLVE THE INFORMALITY PROBLEM (2006)

Anne-Marie Brook and Edward Whitehouse

No. 43 THE ROLE OF DERIVED RIGHTS FOR OLD-AGE INCOME SECURITY OF WOMEN (2006) Jongkyun Choi

No. 42 ACTIVATION STRAGIES AND THE PERFORMANCE OF EMPLOYMENT SERVICES IN GERMANY, THE NETHERLANDS AND THE UNITED KINGDOM (2006)

David Grubb and Peter Tergeist

No. 41 IS TRAINING MORE FREQUENT WHEN THE WAGE PREMIUM IS SMALLER? EVIDENCE FROM THE EUROPEAN COMMUNITY HOUSEHOLD PANEL (2006)

Andrea Bassanini and Giorgio Brunello

No. 40 NEUTRAL OR FAIR? ACTUARIAL CONCEPTS AND PENSION-SYSTEM DESIGN (2006) Monika Queisser and Edward Whitehouse

No. 39 STARTING WELL OR LOSING THEIR WAY? THE POSITION OF YOUTH IN THE LABOUR MARKET IN OECD COUNTRIES (2006)

Glenda Quintini and Sébastien Martin

No. 38 SOCIAL ASSISTANCE POLICY DEVELOPMENT AND THE PROVISION OF A DECENT LEVEL OF INCOME IN SELECTED OECD COUNTRIES (2006)

Willem Adema

No. 37 MEASURES OF MATERIAL DEPRIVATION IN OECD COUNTRIES (2006)

Romina Boarini and Marco Mira d'Ercole

No. 36 FROM INACTIVITY TO WORK: THE ROLE OF ACTIVE LABOUR MARKET POLICIES (2006)

Stéphane Carcillo and David Grubb

No. 35 EMPLOYMENT PATTERNS IN OECD COUNTRIES: REASSESSING THE ROLE OF POLICIES AND INSTITUTIONS (2006)

Andrea Bassanini and Romain Duval

No. 34 AN AGE PERSPECTIVE ON ECONOMIC WELL-BEING AND SOCIAL PROTECTION IN NINE OECD COUNTRIES (2006)

Thai-Thanh Dang, Herwig Immervoll, Daniela Mantovani, Kristian Orsini, Holly Sutherland

No. 33 ALTERNATIVE MEASURES OF WELL-BEING (2006)

Romina Boarini, Asa Johansson and Marco Mira d'Ercole

Recent available working papers can be found on the OECD website: http://www.oecd.org/els/workingpapers.

Other series of working papers available from the OECD include: OECD HEALTH WORKING PAPERS 


\section{RECENT RELATED OECD PUBLICATIONS:}

JOBS FOR YOUTH: BELGIUM (2007)

WOMEN AND MEN IN OECD COUNTRIES (2006)

PENSIONS PANORAMA: RETIREMENT INCOME SYSTEMS IN 53 COUNTRIES

(joint publication with the World Bank) (2006)

SICKNESS, DISABILITY AND WORK: BREAKING THE BARRIERS (VOL. 1) - NORWAY, POLAND AND SWITZERLAND (2006)

INTERNATIONAL MIGRATION OUTLOOK - 2006 Edition

AGEING AND EMPLOYMENT POLICIES: LIVE LONGER, WORK LONGER (2006)

BABIES AND BOSSES: Reconciling Work and Family Life, Volume 4 Canada, Finland, Sweden and the United Kingdom (2005)

PENSIONS AT A GLANCE: Public policies across OECD countries (2005)

EXTENDING OPPORTUNITIES - How active social policy can benefit us all (2005)

SOCIETY AT A GLANCE: OECD Social Indicators (2005)

OECD EMPLOYMENT OUTLOOK (2006)

AGEING AND EMPLOYMENT POLICIES: AUSTRALIA (2005)

AGEING AND EMPLOYMENT POLICIES: AUSTRIA (2005)

AGEING AND EMPLOYMENT POLICIES: CANADA (2005)

AGEING AND EMPLOYMENT POLICIES: DENMARK (2005)

AGEING AND EMPLOYMENT POLICIES: FRANCE (2005)

AGEING AND EMPLOYMENT POLICIES: GERMANY (2005)

AGEING AND EMPLOYMENT POLICIES: IRELAND (2006)

AGEING AND EMPLOYMENT POLICIES: NETHERLANDS (2005)

AGEING AND EMPLOYMENT POLICIES: UNITED STATES (2005)

MIGRATION, REMITTANCES AND DEVELOPMENT (2005)

MIGRATION FOR EMPLOYMENT: BILATERAL AGREEMENTS AT A CROSSROADS (2004)

INCOME DISPARITIES IN CHINA: AN OECD PERSPECTIVE (2004)

BENEFITS AND WAGES: OECD Indicators (2004)

REFORMING PUBLIC PENSIONS: SHARING THE EXPERIENCES OF TRANSITION AND OECD COUNTRIES (2004)

BABIES AND BOSSES: Reconciling Work and Family Life, Volume 3, New Zealand, Portugal, Switzerland (2004)

For a full list, consult the OECD On-Line Bookstore at www.oecd.org 